\title{
Translating Machado DE Assis / TRADUZINDO MACHAdO DE Assis
}

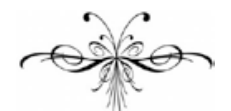 \\ JOHN GLEDSON \\ LUANA FERREIRA DE FREITAS (TRADUTORA) \\ ...la tâche du traducteur ne va pas du mot à la phrase, au texte, à l'ensemble \\ culturel, mais à l'inverse: s'imprégnant par de vastes lectures de l'esprit \\ d'une culture, le traducteur redescend du texte, à la phrase et au mot.
}

This essay springs from my involvement with Machado de Assis over many years as a literary critic, and, in the 1990s, as a translator of Dom Casmurro. I had always thought of the two activities as separate, but recently, I have come to change my
Paul Ricoeur, Sur la Traduction ${ }^{1}$

Este ensaio resulta do trabalho que desenvolvi ao longo de muitos anos como crítico literário da obra de Machado de Assis e, na década de noventa, como tradutor de Dom Casmurro. Sempre pensei nas duas atividades como processos distintos, mas mudei de 
mind, almost entirely as a result of a semester teaching at the PostGraduate Programme for Translation Studies at the Universidade Federal de Santa Catarina. ${ }^{2}$ In particular, I now see that the process of studying translation - my own, and that of others - can illuminate issues much wider than the accuracy or quality of a translation, important as these things are.

I should say from the start that I embrace no particular theory of translation. This is not to say that there is not a lot of profit and interest to be had from reading works on translation just that attempts to codify, generalise and theorise excessively on the topic are often not very helpful. This is especially so in literary translation, where each author has his or her own peculiar style, and presents certain kinds of difficulty (or ease) to the translator. This essay, then, has to do uniquely with Machado de Assis, and in writing it I have found myself speculating on his style, on his prose, on his rhythm, and have also found out how little is written on the topic in the huge corpus of work on him; no doubt because it is a very slippery topic, whose borders are not well-defined, as we will see. Looking at translation, as I hope to show, is one way of illuminating a very interesting and difficult area of study. The choices I and others make give surprising insight into Machado's own choices, if it is only by forcing us to look at the prose in detail. If I have been guided by any theorist, it is Antoine Berman, who says that we should replace the pair "theory/practice", by another, "experience/reflection" - what follows is based on experience, but it is also an attempt to reflect on that experience in useful ways. $^{3}$ opinião há pouco quase que totalmente devido à minha experiência como professor visitante no programa de pós-graduação de Estudos da Tradução da Universidade Federal de Santa Catarina. ${ }^{2}$ Percebo agora que o processo de análise de tradução - a própria e a alheia - pode esclarecer muito além de questões de precisão ou qualidade, apesar da importância destas.

Não sou adepto de nenhuma teoria específica de tradução. Não quero com isso dizer que não se pode tirar muito proveito nem benefício da leitura de trabalhos sobre tradução; mas sim que tentativas de codificar, generalizar e teorizar em excesso sobre o assunto não são em geral muito úteis. Isto fica mais evidente em tradução literária, em que cada autor tem um estilo próprio e apresenta certos tipos de dificuldade (ou facilidade) para o tradutor. Este ensaio, então, tem a ver exclusivamente com Machado de Assis, e, no processo de escrita, surpreendi-me especulando sobre seu estilo, sua prosa, seu ritmo, e descobri que pouco foi escrito a esse respeito na vasta literatura produzida sobre o autor; sem dúvida devido ao caráter movediço da questão, cujos contornos não são bem definidos, como veremos a seguir. A análise de tradução, como espero mostrar, é uma maneira de iluminar uma área de estudo potencialmente muito rica e complexa. As minhas escolhas e as alheias proporcionam insights às vezes surpreendentes do próprio universo machadiano de escolhas, nem que seja só pelo fato de nos forçar a um exame bastante detalhado do texto. Se me deixei guiar por algum teórico, foi por Antoine Berman, que diz que devemos substituir o par "teoria/prática” pelo "experiência/reflexão" - o que se segue tem como fundamento a experiência, mas é igualmente uma tentativa de propor uma reflexão profícua acerca dessa experiência. ${ }^{3}$ 
The subject needs to be seen first in a larger context - in the end, the attention to detail and the attempt to convey something of Machado's rhythm and tone in English, aims at giving him the status he deserves in world literature, but has never (if we are to be honest) achieved outside Brazil, and certainly not in English, the area I am most familiar with. Some speculation about the reasons for this leads us into the history of translation of the novels (I will deal exclusively with Memórias póstumas de Brás Cubas and Dom Casmurro, for reasons of simplicity and space), and from then on to the details of the texts of these translations and the originals; finally, I take a look at some of the problems involved in translating a single short story, "Singular ocorrência". There is no easy transition from one to the other - that is to say, a good translation will not necessarily bring fame - but I think it can be said that it is a sine que non. Inevitably, then, the different approaches used here are not necessarily continuous, rather fragmentary - as is consonant with Berman's combination, “experience” and “reflection”.

\section{I}

Any consideration of the unpleasant fact that, for a writer of his stature, Machado remains relatively unknown outside Brazil, must begin with Daphne Patai's essay, "Machado in English", far as I know the only serious essay on the topic, and which, aside from presenting a multitude of facts about the translations, the way they have been reviewed etc., presents a very disheartening account of the state of affairs, summed up as well as anything in the phrase of the publisher of some American editions of his work - "The sales suck!” In its way, this objective statement sums the
O objeto precisa ser visto em primeiro lugar em um contexto maior; afinal, a atenção ao detalhe e a tentativa de revelar o ritmo e o tom de Machado em inglês pretendem ajudar no processo de conferir-lhe o prestígio merecido na literatura mundial, mas que (sejamos honestos) nunca alcançou fora do Brasil e, certamente, não em língua inglesa, área que me é mais familiar. O exame dos motivos para este fato nos leva à história da tradução dos romances (tratarei somente de Memórias póstumas de Brás Cubas e Dom Casmurro por razões de clareza e espaço) e então à atenção aos detalhes do texto das traduções e dos originais; finalmente, veremos alguns problemas envolvidos na tradução de um conto, "Singular ocorrência". Não há transição tranqüila entre um e outro - por exemplo, uma tradução feliz não necessariamente levará à fama, mas acho que sim se pode dizer que é uma condição sine qua non. É inevitável, pois, que as abordagens usadas aqui não sejam forçosamente contínuas, antes fragmentárias, em consonância com a combinação "experiência” e "reflexão" de Berman.

\section{I}

Qualquer consideração sobre o fato desagradável de que, para um escritor da sua estatura, Machado continua relativamente desconhecido fora do Brasil, deve começar com o ensaio "Machado in English"״ [Machado em inglês] de Daphne Patai, até onde eu sei, o único sério sobre o assunto e que, além de expor numerosos fatos sobre as traduções, a maneira como têm sido resenhadas, entre outras coisas, apresenta um relato desalentador das circunstâncias, resumido na frase do editor de algumas edições norte-americanas de Machado: “As vendas são péssimas!” [“The 
matter up - if we require further testimony, Patai presents it in her account of her visit to her local bookshop (in a university town), which had one copy of Dom Casmurro on its shelves, which had been there for at least a year and a half, and seventeen different editions of thirteen works by Dostoevsky, sometimes with multiple copies.

What are the reasons for this lamentable situation? Patai points to the status of the Portuguese language, whether thought of as the "túmulo do pensamento", or as a "língua de índios" - yet two Portuguese writers, Fernando Pessoa and José Saramago, have achieved considerable fame outside Portugal. Certainly, there has been a general failure to raise the status or profile of Brazilian literature in the world over many, many years, which is probably due to a number of factors. At least four writers, possibly more, were extremely strong contenders for the Nobel Prize, but for one reason or another never made it. Just as an example, almost at random, of this generalized ignorance: a large anthology of shortstories written between 1945 and 1986, edited by Penguin in America, includes, out of a total of 82, 34 translated works, from seventeen countries, seven from Latin America, none from Brazil (or Portugal): one would have thought that at the very least Clarice Lispector should have been present. ${ }^{5}$

It is no doubt partly true that Machado has suffered from this general failure. There are other reasons too, though, that bring us closer to Machado's nature as a writer. The main one, I think, is that he is alone. Great literary successes from "exotic" parts of the globe, for some reason tend to be collective, and each writer reduces the unfamiliarity of the other. The best examples are, first, the Russians - Pushkin, Gogol, Dostoevsky, Tolstoy, Chekhov and sales suck!”] Esta declaração objetiva resume do seu jeito a situação. Se precisarmos de outra evidência, Patai a apresenta no relato de uma visita que fizera a uma livraria local (em uma cidade universitária), que tinha um exemplar de Dom Casmurro nas prateleiras, que estava por lá há pelo menos um ano e meio e dezessete edições diferentes de treze obras de Dostoievski, algumas com vários exemplares.

Que motivos há para esta situação lamentável? Patai chama a atenção para o estatuto da língua portuguesa, tida como "túmulo do pensamento" ou como "língua de índios”; ainda assim, dois escritores portugueses, Fernando Pessoa e José Saramago, conseguiram fama considerável fora de Portugal. Houve decerto uma falha geral na promoção do estatuto ou do perfil da literatura brasileira no mundo ao longo de muitos, muitos anos, o que se deve, provavelmente, a vários fatores. Pelo menos quatro escritores, talvez mais, foram fortes candidatos ao Nobel, mas por uma razão ou outra não ganharam. Só como um exemplo, quase aleatório, desta ignorância generalizada: uma extensa antologia de contos escritos entre 1945 e 1986, editada pela Penguin nos Estados Unidos, inclui, de um total de 82 contos, 34 traduções de dezessete países, sete da América Latina, nenhum conto do Brasil (nem de Portugal). Seria de esperar que ao menos Clarice Lispector estivesse presente. ${ }^{5}$

Em parte, é verdade que Machado sofreu com essa falha geral. Há, contudo, outras razões também, que nos aproximam da natureza de Machado como escritor. A principal, acredito, é que ele está sozinho. Grandes sucessos literários de partes “exóticas” do globo, por alguma razão, tendem a ser coletivos, e cada escritor ameniza o estranhamento do outro. Os melhores exemplos são, em primeiro lugar, os russos do século dezanove, Pushkin, Gogol, 
others form a kind of tradition, and portray together a kind of society of which we become gradually familiar, so that the novels, plays etc., become easier to understand; and second, the Latin American "boom" of the late sixties and seventies, in which writers like Borges, Alejo Carpengtier, García Márquez, Vargas Llosa and Carlos Fuentes and others less well-known reinforced one another - even though they were from different countries and generations. The rubric of "magical realism", which had repercussions in other parts of the world (the fiction of Salman Rushdie, for example), also boosted this effect.

By contrast, the great writers of Brazilian literature Machado de Assis, Graciliano Ramos, Carlos Drummond de Andrade, João Guimarães Rosa, Clarice Lispector, João Cabral de Melo Neto and others - have tended to be somewhat isolated figures in their own country, impossible to fit into the Latin American model, for all the efforts on their behalf. They have, all of them, very strong, and strongly contrasting characters; they are also (apart perhaps from Guimarães Rosa, the most difficult to translate) disappointingly unexotic, and fail to fulfil certain expectations of what Latin American literature "should be". The real successes in terms of sales are the over-Brazilian "exotic", sex-and-cooking "baianismo" of Jorge Amado, and the "nonBrazilian” Paulo Coelho. ${ }^{6}$

With Machado, however, this isolation is compounded by the fact that he is a strange figure in the context of literary history too, and this has led to uncertainty - I am tempted to say a fatal uncertainty - about how to "sell" him. Many have seen him primarily as a literary experimenter, someone ahead of his time,
Dostoievski, Tolstoi, Tchekhov e outros, que formam um tipo de tradição e que retratam um tipo de sociedade com a qual nos familiarizamos de maneira gradual, tanto que romances, peças e outras obras se reforçaram mutuamente e assim tornaram-se mais fáceis de entender; e, em segundo, o "boom" latinoamericano do fim dos anos sessenta e setenta, quando escritores como Borges, Alejo Carpentier, García Márquez, Vargas Llosa e Carlos Fuentes e outros menos conhecidos complementavam-se, ainda que fossem de países e gerações diferentes. A rubrica de "realismo mágico", que repercutiu em outras partes do mundo (a ficção de Salman Rushdie, por exemplo), também intensificou esse efeito.

Na contramão, os grandes escritores da literatura brasileira, Machado de Assis, Graciliano Ramos, Carlos Drummond de Andrade, João Guimarães Rosa, Clarice Lispector, João Cabral de Melo Neto e outros, tendiam de alguma maneira a ser casos isolados em seu próprio país, impossíveis de se encaixar no modelo latino-americano, apesar de todos os esforços nesse sentido. Todos tinham personalidades muito fortes e muito distintas entre si, eram, além disso (com exceção talvez de Guimarães Rosa, o mais difícil de traduzir), decepcionantemente "não-exóticos” e não conseguiam satisfazer certas expectativas de como "deveria ser" a literatura latino-americana. Os maiores sucessos de venda são o brasileiro exótico ao extremo, Jorge Amado, com seu baianismo de sexo e cozinha, e o nada brasileiro Paulo Coelho. ${ }^{6}$

Contudo, com Machado este isolamento se mistura ao fato de ele ser uma figura excepcional no contexto da história literária também, o que gerou a incerteza - ouso dizer, uma incerteza fatal - de como "vendê-lo". Muitos o viram antes de mais nada como um experimentador literário, alguém adiante do 
who already in 1880 (taking Memórias póstumas de Brás Cubas as an example) was making fun of traditional realist ways of writing fiction, and playing with such things as unreliable firstperson narration, digressions, an ironic and playful dialogue with the reader etc. In particular, when the novels were first translated in the United States in the 1950s, this was the view taken of him John Barth, whose first novel, The Floating Opera, was highly influenced by Machado, has said that Dom Casmurro seemed to him, in those days, as if it could have been written then, in the 1950s. ${ }^{7}$ This has very often meant that he has been sold on this basis - a typical example is the inclusion of Epitaph of a Small Winner (William Grossman’s translation of Memórias póstumas), in the sixties, in a series of "Penguin Modern Classics", along with the likes of Virginia Woolf and James Joyce. This tendency is still very much alive - the recent new translation of the Memórias published by Oxford University Press has on its cover a (Mexican) cubist painting from the 1920s, plainly intended to show the modern - disintegration of point of view.

In a sense, there is nothing wrong in this - Machado was in advance of his time, and we cannot gainsay the evidence of the likes of Barth, Susan Sontag, Michael Wood, and even Woody Allen who read him and enjoy his novels in this way. My argument against this point of view is somewhat different. By putting the emphasis so strongly on formal aspects of his novels, they have become utterly separated from their context, and so an important part of their very nature is passed by. seu tempo, que já em 1880 (tomando como exemplo as Memórias póstumas de Brás Cubas) zombava das tradicionais formas realistas de escrever ficção e se aventurando em coisas como narração suspeita em primeira pessoa, digressões, diálogo irônico e brincalhão com o leitor, entre outras. Quando os seus romances foram traduzidos pela primeira vez nos Estados Unidos, nos anos cinqüenta, essa era a visão que se tinha dele - John Barth, cujo primeiro livro, The Floating Opera [A ópera flutuante], foi muito influenciado por Machado, disse que Dom Casmurro lhe parecia, naquele tempo, como se tivesse sido escrito nos anos cinqüenta ${ }^{7}$. Isto significa que ele tem sido vendido assim; um exemplo representativo sendo a inclusão de Epitaph of a Small Winner (tradução de William Grossman do Memórias póstumas), nos anos sessenta, numa série dos "Penguin Modern Classics" acompanhado de similares de Virginia Woolf e James Joyce. Esta tendência ainda vigora: a nova tradução das Memórias, publicada pela Oxford University Press, tem na capa uma pintura cubista (mexicana), dos anos vinte, com a clara intenção de mostrar a desintegração (moderna) do ponto de vista.

Até certo ponto, não há nada de errado com isso Machado estava à frente de seu tempo e não podemos discutir o testemunho de Barth, Susan Sontag, Michael Wood e até mesmo Woody Allen que leram Machado e o apreciaram assim. O meu argumento contrário a esse ponto vista é um tanto diferente. Ao enfatizar com tanta veemência os aspectos formais dos seus romances, eles foram apartados de maneira definitiva do contexto e, assim, um aspecto importante dos romances, e intrínseco a eles é desconsiderado. 
This, in fact, is not entirely true - the truth is more subtle, and in the end worse for Machado's reputation. In the attempt to make him interesting, writers regularly (and rightly enough, of course) mention his colour, his poor background, his epilepsy, and so on. The trouble is that none of this seems to appear within the books - contrast the case of Dostoevsky, also an epileptic. The result is that there are two Machados - roughly speaking, the Brazilian and the modernist - but they don't meet. This is not just a somewhat regrettable fact - it goes to the heart of why he has failed to make an impact. The indissolubility of form and content is not just a critical nostrum - it is a normal fact of reading. Henry James and Joseph Conrad - more or less Machado's contemporaries - were also included in the "Penguin Modern Classics”, if my memory serves me right. There, because they are being read in the original, and their average reader is somewhat familiar with their context - however unfamiliar nineteenthcentury London or Boston, the Africa of Heart of Darkness or the South America of Nostromo may be - this is a much less serious matter. There is an important sense in which James and Conrad were writing “for” today's British or American reader in a way Machado was not.

A surely unsurpassable example of the harm this divorce between form and content can do can be seen in recent "promotion" given to Machado by Harold Bloom, in his recent book Genius, placing him amongst the world's hundred greatest writers. ${ }^{8}$ Bloom explicitly denies Machado any connection with his milieu: "I don’t wish to deny originality and creative energy to the Brazilian master, simply to note that Sterne's spirit freed Machado from any merely nationalist demands that Brazil might have made
De fato, isto não corresponde a toda a verdade - a verdade é mais sutil e, no fim das contas, pior para a reputação de Machado. Na tentativa de torná-lo mais atrativo, os escritores normalmente (e com toda a razão, claro) mencionam a cor, a origem pobre, a epilepsia. A questão é que nada disso aparece nos seus livros - diferentemente, por exemplo, de Dostoievski, também epilético. O resultado é que há dois Machados, grosso modo o brasileiro e o modernista, mas eles não se unem. Este não é apenas um fato um tanto lamentável - talvez seja a razão principal de ele não ter causado impacto. A indissolubilidade de forma e conteúdo não é mero cura-tudo crítico - é um fato natural da leitura. Henry James e Joseph Conrad - mais ou menos contemporâneos de Machado - também foram incluídos na série "Penguin Modern Classics", se não me falha a memória. Nesse caso, porque são lidos na língua original e o seu leitor médio está em alguma medida familiarizado com o contexto - ainda que a Londres ou a Boston do século XIX, a África de Heart of Darkness [O coração das trevas] ou a América do Sul de Nostromo possam parecer distantes - esta relação forma/ conteúdo é uma questão menor. É importante ressaltar que, de certo modo, James e Conrad estavam escrevendo "para" o leitor britânico ou norteamericano atual - o caso de Machado é diferente.

Um exemplo certamente imbatível do dano provocado por este divórcio da forma e do conteúdo pode ser visto com a recente "promoção" que Harold Bloom concedeu a Machado, colocando-o entre os cem maiores escritores do mundo. ${ }^{8}$ Explicitamente, Bloom nega toda relação com o meio: "Não quero negar originalidade e energia criativa ao mestre brasileiro, mas apenas registrar que o espírito de Sterne libertou Machado de quaisquer exigências meramente nacionalistas que o Brasil porventura 
on him. Machado de Assis is a kind of miracle, another demonstration of the autonomy of literary genius, as far as factors like time and place, politics and religion are concerned, and of freedom from any type of contextualisation that supposedly determines human talent". ${ }^{9}$ In other ways, too, Bloom's chapter is not to be highly recommended - he praises Gregory Rabassa's translations, which, as we will see, is almost a proof that he had not read them, and says that the (relative) failure of Quincas Borba is due to the fact that it is narrated in the third person, "not Machado's strong point". ${ }^{10}$

In a sense, however, these problems are not just a comment on foreign reactions to Machado. Some of their origins can be found in the very nature of Machado's work itself, and here we can begin to see the importance of translation. I can begin with the reaction of a friend of mine, a Catalan, not an expert on Portuguese, but who reads the language and is an expert on late nineteenth-century fiction. When he read Eça de Queirós, he was delighted - as who can fail to be? But when he turned to Machado, he found something strangely off-putting, a lack of the same satirical verve and humour, perhaps. Of course, it is easy to say that Machado is more subtle and ultimately more original and corrosive than Eça, but the reaction is understandable just the same. Consider the reader faced with Dom Casmurro. First, he has to buy a novel with an impenetrable title. Then, at the end of the short first chapter, he has to face the fact that he is unable to do what, admittedly, the narrator tells him not to do - look up a word in a (Portuguese) dictionary. Notice, too, that there is little the translator can do about this - he could put in a footnote, but aside from being in itself an admission of failure, this draws too much attention to the detail. ${ }^{11}$ Then in Chapter 3 , when we finally get to pretendesse lhe impor. / Machado de Assis é uma espécie de milagre, mais uma demonstração de da autonomia do gênio literário, quanto a fatores como tempo e lugar, política e religião, e todo o tipo de contextualização que supostamente produz a determinação dos talentos humanos". ${ }^{9}$ Em outros aspectos também o capítulo de Bloom não é altamente recomendável - elogia as traduções de Gregory Rabassa, o que é, como veremos, quase um prova de que não as leu, e diz que o (relativo) fracasso de Quincas Borba e deve ao "fato de ser narrado na terceira pessoa, que não é o forte de Machado". ${ }^{10}$

No entanto, de certo modo, estes problemas não são apenas uma observação sobre as reações a Machado no estrangeiro. Algumas de suas origens podem estar na própria essência da obra de Machado, e aqui podemos começar a vislumbrar a importância da tradução. Posso começar com a reação de um catalão, amigo meu, que não é especialista em português, mas o lê e é especialista em ficção do fim do século XIX. Quando ele leu Eça de Queirós, ficou encantado - e quem não ficaria? Mas quando leu Machado, encontrou algo estranhamente desconcertante, talvez uma ausência daquela mesma verve satírica e do humor. É claro que é fácil dizer que Machado é mais sutil e no fim das contas mais original e corrosivo que Eça, mas a reação é compreensível mesmo assim. Pense num leitor estrangeiro de Dom Casmurro. Em primeiro lugar, ele tem que comprar um livro cujo título é impenetrável. Depois, no fim do curto primeiro capítulo, ele tem que enfrentar o fato de que ele é incapaz de fazer o que o narrador lhe diz expressamente para não fazer: procurar uma palavra no dicionário de português. É necessário que se atente para o fato de que o tradutor não pode ajudar muito; ele poderia inserir uma nota de rodapé, mas, além de 
see some action, the narrator tells us, somewhat rudely, that, although "the year [1857] is a trifle remote, I have no intention of changing the dates of my life just to suit people who don't like old stories”.

We have to face the fact that Machado was himself a somewhat secretive, even aggressively secretive, writer: as Múcio Leão said of him, "se delicia em ser incompreendido". ${ }^{12}$ "Acabemos com este costume do escritor dizer tudo, à laia de alvissareiro", he said, in a crônica. ${ }^{13}$ One can feel the small thrill of pleasure when, in one of his crônicas, he sees a sign "Opacamse vidros". ${ }^{14}$ Worse still - he is not secretive out of a belief that literature should be hermetic, like the French symbolists who were his contemporaries. On the contrary, he is anxious at times to take his reader along with him, to tell him (as in Memórias póstumas de Brás Cubas) that the love-interest will be along soon. ${ }^{15}$ Rather, we have to face the fact that he was secretive in part because he had to be, for whatever reasons - either because of his relationship with his readers, or because of the material he was dealing with, or both.

Worse still - perhaps worst of all - is that this secretiveness is itself, to a degree, a secret. After all, we are used enough to aggressive narrators, and these tricks both predate Machado - he was extremely familiar himself with the Sternian tradition - and carry on long after him. What is more frustrating yet is that his novels can look perfectly normal to "normal" European or North-American eyes, yet in the end be elusive by those very standards. The best example of this I have come across is in Patai's essay, where she chronicles the changing viewpoint of representar uma confissão de fracasso, chamaria demais a atenção para o detalhe ${ }^{11}$. Então, no terceiro capítulo, quando finalmente algo acontece, o narrador nos informa, um tanto ríspido, que, “o ano [1857] é que é um tanto remoto, mas eu não hei de trocar as datas à minha vida só para agradar às pessoas que amam histórias velhas".

Temos que aceitar o fato de que Machado era um pouco reticente, talvez um escritor agressivamente reticente. Múcio Leão disse que ele "deliciava-se em ser incompreendido"; ${ }^{12}$ disse ainda em uma crônica: "Acabemos com este costume do escritor dizer tudo, à laia de alvissareiro”. ${ }^{13}$ Dá para sentir um estremecimento de prazer quando, em uma crônica, ele lê em uma placa: "Opacamse vidros.”14 $\mathrm{O}$ pior é que ele não é reticente porque acredita que a literatura deva ser hermética, a exemplo dos simbolistas franceses, seus contemporâneos. Pelo contrário, fica às vezes ansioso por levar o leitor com ele, por contar (como em Memórias póstumas de Brás Cubas) que o romance (no sentido de intriga amorosa) logo aparecerá $^{15}$. Antes, temos que aceitar que ele era reticente em parte porque ele tinha que ser, quaisquer que fossem as razões para isso, fosse pela relação que tinha com seus leitores, ou pelo material com o qual lidava, ou ambas.

Pior ainda, talvez o pior de tudo, é que essa reticência é ela mesma, até certo ponto, um segredo. Afinal, estamos bastante acostumados a narradores agressivos, e tal artifício antecede Machado - ele estava bem familiarizado com a tradição sterniana - e continua existindo depois dele. O mais frustrante é que seus romances podem parecer perfeitamente normais para um olhar europeu ou norte-americano "normal" e, ainda assim, no fim das contas, serem fugidios de acordo com estes mesmos padrões. $\mathrm{O}$ melhor exemplo que já vi disso está no ensaio de Patai, em que ela 
one of Machado's translators, Robert Scott-Buccleuch, who, having proclaimed that "for the European (...) both the cultural shock [of reading Machado] and what we might call the linguistic shock are relatively mild”, later, in his introduction to his translation of Dom Casmurro, lists a number of reasons why he is "virtually impossible to render in English". ${ }^{16}$ What is it about Machado's work that evades definition, and which, I suspect, was the main reason for my Catalan friend's frustration?

Of course this is a complex matter, and it must be emphasised that there is no simple answer to it, nor does this essay pretend to provide one. However, one indication that it may not be entirely insoluble comes, not from the world of translation, or of foreign reception of Machado, but from Brazilian criticism itself, which has also had its difficulties with his work. From being the Brazilian Anatole France, to the writer who echoes of Dostoevsky and Freud, quite possibly without having read them (Helen Caldwell's translation of "O alienista" was entitled "The Psychiatrist”), we are now in a completely different field. The watershed came in 1977, with the publication of Roberto Schwarz's Ao vencedor as batatas, followed in 1991 by Um Mestre na Periferia do Capitalismo. To simplify matters, I shall quote only some words from the opening of the latter book: Schwarz says that the "volubility" characteristic of the style and structure of Memórias póstumas de Brás Cubas is both “a) a rule for the composition of the narrative and b) the stylization of a kind of conduct characteristic of the Brazilian ruling class."17 In other words, the style of the Memórias, narrated by a frivolous, blithely inconsistent member of the ruling class, is itself socially inspired there could hardly be a tighter connection between form and registra o ponto de vista movediço de um dos tradutores de Machado, Robert Scott-Buccleuch, que, tendo afirmado que "para o europeu (...) tanto o choque cultural [relativo à leitura de Machado] quanto o que podemos chamar de choque lingüístico são relativamente tênues", mais adiante, na introdução à sua tradução de Dom Casmurro, lista várias razões de ele ser "praticamente impossível de verter para o inglês”. ${ }^{16}$ O que há na obra de Machado que foge à definição e que, desconfio, era o principal motivo da frustração do meu amigo catalão?

É, sem dúvida, uma questão complexa e deve ser ressaltado que não há uma resposta simples para ela, tampouco este ensaio se propõe a respondê-la. Contudo, uma indicação de que ela pode não ser totalmente insolúvel vem, não do universo da tradução nem da recepção de Machado em outras culturas, mas da crítica brasileira, que teve igualmente as próprias dificuldades relacionadas ao seu trabalho. De Anatole France brasileiro ao escritor que ecoa Dostoievski e Freud, provavelmente sem os ter lido (a tradução de Helen Caldwell de "O alienista” recebeu o título "The Psychiatrist" [O psiquiatra]), estamos agora em um terreno inteiramente diferente. O divisor de águas apareceu em 1977, com a publicação de Ao vencedor as batatas de Roberto Schwarz, seguido de Um mestre na periferia do capitalismo de 1991. Para simplificar, citarei apenas algumas palavras da introdução do segundo. Schwarz diz ali que a "volubilidade" típica do estilo e da estrutura de Memórias póstumas de Brás Cubas é tanto "a) uma regra para a composição da narrativa quanto b) estilização de um tipo de conduta característica da classe dominante brasileira”. ${ }^{17}$ Ou seja, o estilo das Memórias, narradas por um membro da classe dominante, frívolo e despreocupadamente inconsistente, tem inspiração social - difícil 
content. These views, along with others expounded by Schwarz, have found a very wide degree of acceptance in Brazil, and Schwarz himself has won some recognition abroad. Could we be on the way to solving the division between form and context of which Bloom is only the most grotesque example? Speaking for myself, and as someone who had lived in Brazil for a year in the early seventies, Ao vencedor as batatas literally made me able to read Machado de Assis - I had tried before and been frustrated; above all, Schwarz's argument about the centrality of favour in the novels made me understand how the characters were related: it was the gateway into his world.

Of course, a change in the critical climate is quite a different thing from making a writer popular, or making his work better known to the non-Brazilian reader. But it is part of that process, and the main reason why I translated some of Roberto Schwarz's essays into English in 1991, and, more recently, Um mestre na periferia do capitalismo. Such books do not sell in great numbers, but they do project a new light on the author, and bring him to life in a different way. It is probable that the task of giving Machado a higher profile in English has only just begun, and that it will be a long process, but at least the basis of his reputation will be more solid, and less subject to the fits and starts of the last fifty or so years.

\section{II}

In this section, I want to look at the history of translation of Machado into English, and particularly at the history of the translation of two of the major novels, the most famous, Memórias imaginar um encaixe mais perfeito de forma e conteúdo. Estas percepções, além de outras expostas por Schwarz, tiveram ampla aceitação no Brasil, e e as suas idéias até conquistaram um certo reconhecimento estrangeiro. Estaríamos no rumo certo para dissolver a cisão entre forma e conteúdo da qual Bloom é apenas o exemplo mais grotesco? $\mathrm{Na}$ minha opinião, como alguém que morou um ano no Brasil, no início dos anos setenta, Ao vencedor as batatas tornou-me literalmente capaz de ler Machado - tinha tentado antes sem sucesso e, acima de tudo, a discussão de Schwarz sobre a centralidade das relações de favor nos romances me possibilitou entender como os personagens eram apresentados: foi o portão de entrada para esse mundo.

Uma mudança do clima na crítica de um autor não implica torná-lo famoso, tampouco tornar sua obra conhecida para o leitor estrangeiro. Mas é parte do processo e a principal razão de eu ter traduzido para o inglês alguns ensaios de Roberto Schwarz, em 1991, e, mais recentemente, Um mestre na periferia do capitalismo. Este tipo de literatura não vende muito, mas dá um novo fôlego ao autor e o traz à vida de uma outra maneira. É provavel que a tarefa de dar a Machado um perfil mais elaborado em inglês tenha apenas começado e que se estenderá por alguns anos, mas, pelo menos, a sua reputação terá fundamentos mais sólidos e estará menos suscetível aos altos e baixos dos últimos cinqüenta anos.

\section{II}

Nesta seção, tratarei da história da tradução de Machado para o inglês, em especial, da história da tradução dos dois maiores romances, os mais famosos, Memórias póstumas de Brás Cubas e 
póstumas de Brás Cubas and Dom Casmurro. There have been, to my knowledge, three translations of each, belonging to two periods. The first translations were from the 1950s, and were the result of a single effort by the Noonday Press (New York), and the enthusiasm of its founder and owner, Cecil Hemley, who wrote a novel, The Experience, in which he acknowledged Machado's influence $;^{18}$ in much the same way, as has been said, John Barth acknowledged the same influence on The Floating Opera - one notable aspect of the reception of Machado in those days is that it was, to some degree, creative, and seemed to fit in with the intellectual, or at least the fictional, climate of the times. The three central novels were translated by, respectively, William Grossman (Brás Cubas), Clotilde Wilson (Quincas Borba), and Helen Caldwell (Dom Casmurro). These translations have all been reprinted since, both in the United States and Britain, though they have been taken over by other presses, significantly perhaps the University of California Press - it may be that this indicates a somewhat more restricted, academic readership than would be ideal, though Penguin, as noted above, did include Epitaph of a Small Winner in its Modern Classics Series, and it has been printed too by Bloomsbury, a very reputable and successful medium-sized publisher. Grossman and Caldwell also collaborated in the translation of some ten short stories (including "O Alienista”). ${ }^{19}$ In 1955, a further translation, by E. Percy Ellis, of Memórias póstumas de Brás Cubas appeared in Brazil, published by the Instituto Nacional do Livro - it was never reprinted, and was generally (and rightly) condemned as unworthy, in particular in a very negative review by Raymundo Magalhães Júnior. ${ }^{20}$
Dom Casmurro. Há, pelo que sei, três traduções de cada, relativas a dois períodos. As primeiras traduções são dos anos cinqüenta e resultam de um esforço da Noonday Press de Nova York e do seu fundador e proprietário, Cecil Hemley, que escreveu o romance The Experience [A experiência], no qual admite a influência de Machado ${ }^{18}$; da mesma forma, como já foi dito anteriormente, John Barth admitiu a mesma influência no The Floating Opera [A ópera flutuante]. Um aspecto notável da recepção de Machado naquele tempo é que era, até certo ponto, criativa e parecia se encaixar no panorama intelectual, ou pelo menos, no ficcional de então. Os três romances centrais foram traduzidos respectivamente por William Grossman (Memórias póstumas de Brás Cubas), Clotilde Wilson (Quincas Borba) e Helen Caldwell (Dom Casmurro). As três foram reeditadas tanto nos Estados Unidos quanto na Inglaterra, apesar de terem sido adquiridas por outras editoras, sugestivamente talvez a University of California Press, o que pode apontar para um leitorado um pouco mais restrito e acadêmico que o ideal, embora a Penguin, como exposto anteriormente, tenha incluído, na sua coleção Modern Classics Series, o Epitaph of a Small Winner [Memórias póstumas de Brás Cubas], que também foi publicado mais recentemente pela Bloomsbury, uma próspera editora de médio porte, muito respeitada. Grossman e Caldwell também colaboraram para a tradução de cerca de dez contos (incluindo "O alienista") em The Psychiatrist and Other Stories. ${ }^{19}$ Em 1955, outra tradução, de E. Percy Ellis, das Memórias póstumas de Brás Cubas apareceu no Brasil, publicada pelo Instituto Nacional do Livro - nunca foi reimpressa, e foi condenada universalmente (e corretamente) como indigna do original, em particular numa resenha muito negativa de Raymundo Magalhães Júnior. ${ }^{20}$ 
Apart from this last case, these translations of the novels are good, readable, adequate versions at the least. Criticisms can be made - Grossman at times intervenes to "explain” Machado's irony, intending no doubt to be helpful, but in fact destroying the tense relationship Machado intended to have with his reader, in part by forcing him to think; Caldwell's version of Dom Casmurro is, for my taste, somewhat wooden, and, as Patai, in general her supporter, says, "at times perhaps [she is] still somewhat in thrall to the original language" ${ }^{\text {21 }}$. They were, in sum, adequate translations, but the time had come for new versions

More recently, in 1991, Dom Casmurro was given a new English version by Robert Scott-Buccleuch. Originally published by Peter Owen Ltd., a small London publisher, it was taken over by Penguin, and placed, this time, into their "Classics" series - a sign of changing times perhaps. This translation has since disappeared from the market, after the scandal of its omission of nine chapters became public knowledge.

In the mid-1990s, the Oxford University Press launched a new and ambitious scheme to publish a large number of Latin American classics in new translations. Many works, in fact, were translated for the first time, but the first group included Machado's three central novels, and I was invited to translate Dom Casmurro - the other two novels were translated by Gregory Rabassa, renowned for his translations of Latin American fiction, notably Cien años de soledad. I will deal with my own translation last, since it differs in important ways from Rabassa's, most obviously by having explanatory footnotes.
Estas traduções (fora a última) dos romances são, no mínimo, boas, legíveis e adequadas. É possível fazer algumas críticas; Grossman, por exemplo, às vezes, intervém para "explicar" a ironia de Machado, com a clara intenção de ajudar, mas, na verdade, destruindo a tensão que Machado pretendia estabelecer com o seu leitor, forçando-o em parte a pensar também, por alguma razão omite o famoso epígrafe, "Ao verme que primeiro roeu as frias carnes..."; a versão de Caldwell para Dom Casmurro, por outro lado, é, na minha opinião, um tanto engessada e Patai, em geral sua defensora, diz que "às vezes, talvez [ela fique] ainda um pouco submissa à língua original”21. Elas eram no geral traduções adequadas, mas já era tempo para novas versões.

Mais recentemente, em 1991, Dom Casmurro recebeu uma nova versão em inglês de Robert Scott-Buccleuch. Publicada originalmente pela Peter Owen, uma pequena editora em Londres, ela foi adquirida pela Penguin e incluída, desta vez, na série "Classics" - um indício talvez de que os tempos são outros. Esta tradução sumiu do mercado depois que o escândalo da omissão de nove dos seus capítulos se tornou público.

Em meados dos anos noventa, a Oxford University Press deu início a um projeto novo e ambicioso de publicar várias novas traduções de clássicos latino-americanos. Muitos deles, na verdade, foram nessa ocasião traduzidos pela primeira vez. O primeiro grupo de obras incluía os três romances centrais de Machado, e fui convidado para traduzir Dom Casmurro; os outros dois foram traduzidos por Gregory Rabassa, famoso pelas suas traduções de ficção latino-americana, em especial Cien años de soledad [Cem anos de solidão]. Abordarei a minha tradução no final desta seção, já que se diferencia da de Rabassa em aspectos 
While in many ways the Library of Latin America has been a laudable enterprise, I can't say that my experience was entirely satisfactory; more important than this, however, Rabassa's translations are themselves quite inadequate, plagued with mistakes, with bad English, clumsy sentences, lack of respect for Machado's punctuation, etc. The explanation seems to lie primarily in simple carelessness and laziness. This was evidenced in the original hardback printing by a number of typographical errors, some of them quite grotesque - Erasmus's In Praise of Folly appeared as In Praise of Polly, "statues" became "statutes", "hard" became "heard" and so on. It is obvious that both translator and publisher thought it quite enough to put on the spell-check, forgetting that it will not pick up words that are words, though not the right word. Both, of course, are to blame, and the laziness can be seen in other ways - on the publishers' part, by a lack of care or consultation over the covers (which, in the hardback version emphasised the words "de Assis" instead of "Machado de Assis"), and, what is much more serious, in the translator's case by a myriad of mistakes and failures of various kinds, which make reading the book a frustrating experience.

This failure, as far I know, has not become common knowledge in the way that Scott-Buccleuch's extraordinary decision has, but it is almost as important, if not more so, because the fact that a prestigious publisher and a prestigious translator have put their names on a bad translation (I use the adjective advisedly) means that the opportunity, which the OUP had, of putting a really good, faithful translation on the market has been significativos, mais notadamente pelo uso de notas de rodapé explicativas.

Enquanto que, em vários aspectos, a Library of Latin America tem sido um projeto louvável, não posso dizer que a minha experiência foi de todo satisfatória; mais importante que isso, contudo, as traduções de Rabassa são inadequadas, infestadas de erros, em um inglês sofrível, com frases deselegantes, desrespeito à pontuação de Machado e assim por diante. A explicação parece estar primeiramente no descuido e na preguiça pura e simples. Isto foi comprovado na edição original de capa dura por inúmeros erros tipográficos, alguns grotescos: In Praise of Folly [Elogio da loucura] de Erasmo virou In Praise of Polly, "statues" [estátuas] viraram "statutes" [estatutos], "hard" [duro] virou "heard" [escutado] e assim por diante. Ficou claro que tanto o tradutor quanto o editor acreditaram ser suficiente revisar o texto com o corretor ortográfico, esquecendo-se que este dispositivo lida com palavras do léxico, sem considerar o contexto. A culpa, óbvio, cabe aos dois e a preguiça pode ser vista de outras maneiras: da parte da editora, pelo desleixo com a capa, que, na versão de capa dura, realçou "de Assis" ao invés de "Machado de Assis", e, o que é mais grave, no caso do tradutor, uma miríade de erros e falhas de natureza das mais variadas, o que torna a leitura do livro uma experiência frustrante.

Essa omissão, até onde eu sei, não se tornou pública como a de Scott-Buccleuch, mas é quase tão grave quanto, se não for mais grave, pois o fato de uma editora e um tradutor conceituados assinarem uma péssima tradução (faço uso deliberado do adjetivo) significa que a oportunidade que a editora teve de lançar no mercado uma tradução boa e fiel foi jogada fora da maneira mais irreponsável. Que editora pagaria por uma nova tradução? E quem 
wilfully thrown away. Who would take the time and effort, which publisher would pay for, a new translation, having to compete with two such respectable names?

These are serious allegations, and some proof is required. It would be impossible to go through every chapter, so one passage, chosen more or less at random, will have to suffice. ${ }^{22}$ I will place side by side the original, Grossman's, and Rabassa's translation of a short passage, from Chapter 68 of the novel, for the differences to be made clear. At this moment Brás has just set up his love-nest in Gamboa, when he has this embarrassing encounter: dedicaria tempo e envidaria esforços para fazê-la, tendo que competir com dois nomes tão abalizados?

São acusações graves que necessitam de fundamentação. Seria impossível cotejar cada capítulo; assim, creio que um trecho escolhido mais ou menos ao acaso bastará ${ }^{22}$. Exporei em três colunas paralelas o original, a tradução de Grossman e a de Rabassa de um trecho do capítulo 68 do romance para que as discrepâncias se evidenciem. No trecho em questão, Brás acabou de construir o seu ninho de amor na Gamboa, quando tem um encontro constrangedor:

\begin{tabular}{|c|c|c|}
\hline $\begin{array}{l}\text { Tais eram as reflexões que eu vinha } \\
\text { fazendo, por aquele Valongo fora, logo } \\
\text { depois de ver e ajustar a casa. Interrompeu- } \\
\text { me um ajuntamento; era um preto que } \\
\text { vergalhava outro na praça. O outro não se } \\
\text { atrevia a fugir; gemia somente estas únicas } \\
\text { palavras: -- "Não, perdão, meu senhor; meu } \\
\text { senhor, perdão!” Mas o primeiro não fazia } \\
\text { caso, e, a cada súplica, respondia com uma } \\
\text { vergalhada nova. } \\
\text {-- Toma, diabo! dizia ele, toma mais } \\
\text { perdão, bêbado! } \\
\text { Meu senhor! gemia o outro. } \\
\text {-- Cala a boca, besta! replicava o } \\
\text { vergalho. } \\
\text { Parei, olhei... Justos céus! Quem havia }\end{array}$ & $\begin{array}{l}\text { Such were my reflections as I walked } \\
\text { through Valongo after looking at the house } \\
\text { and making arrangements to rent it. My } \\
\text { thoughts were interrupted by the sight of a } \\
\text { crowd, gathered around a Negro who was } \\
\text { whipping another Negro. The victim did not } \\
\text { try to flee; he merely groaned. "No, have } \\
\text { mercy, master; master, have mercy!” But } \\
\text { the other responded to each supplication } \\
\text { with a new lash of the whip. } \\
\text { "Take that, devil!" he was saying. } \\
\text { "Here's some more mercy for you, } \\
\text { drunkard." } \\
\text { "Master!" groaned the victim. } \\
\text { "Shut your mouth, beast!”**** }\end{array}$ & $\begin{array}{l}\text { Such were my reflections as I walked } \\
\text { along Valongo right after seeing and } \\
\text { arranging for the house. They were } \\
\text { interrupted by a gathering of people. It was } \\
\text { because of a black man whipping another in } \\
\text { the square. The other one didn't try to run } \\
\text { away. He only moaned these words: } \\
\text { "Please, I'm sorry, master. Master, I’m } \\
\text { sorry!” but the first one paid no attention } \\
\text { and each entreaty was answered with a new } \\
\text { lashing. } \\
\text { "Take that, you devil”, he was saying, } \\
\text { "There's sorry for you, you drunk!” } \\
\text { "Master!”, the other one was moaning. } \\
\text { "Shut your mouth, you animal!”,the } \\
\text { whipper replied. }\end{array}$ \\
\hline
\end{tabular}




\begin{tabular}{|c|c|c|}
\hline $\begin{array}{l}\text { de ser o do vergalho? Nada menos que o } \\
\text { meu moleque Prudêncio, -- o que meu pai } \\
\text { libertara alguns anos antes. Cheguei-me; ele } \\
\text { deteve-se logo e pediu-me a bênção; } \\
\text { perguntei-lhe se aquele preto era escravo } \\
\text { dele. } \\
\text {-- É, sim, nhonhô. } \\
\text {-- Fez-te alguma coisa? }\end{array}$ & $\begin{array}{l}\text { The whipper was none other than my slave } \\
\text { boy Prudêncio, whom my father had freed } \\
\text { some years earlier. I approached him; he } \\
\text { stopped immediately and kissed my hand. I } \\
\text { asked him whether the other Negro was his } \\
\text { slave. } \\
\text { "Yes, nhonhô, he is. } \\
\text { "Has he done something?"24 }\end{array}$ & $\begin{array}{l}\text { I stopped to look... Good Lord! And } \\
\text { who did the one with the whip turn out to } \\
\text { be? None other than my houseboy } \\
\text { Prudêncio - the one my father had freed } \\
\text { some years before. He came over to me, } \\
\text { having ceased immediately, and asked for } \\
\text { my blessing. I inquired if that black man } \\
\text { was his slave. } \\
\text { "He is, yes, little master. } \\
\text { "What did he do?"25 }\end{array}$ \\
\hline
\end{tabular}

Comparisons of the two translations are almost always favourable to Grossman's. It is plain, in fact, that the earlier translation has not been used by Rabassa - but more than anything else, it seems obvious that very little thought has been given by him to resolve problems posed by the Portuguese, which are no doubt tricky, but which, with effort, could have been solved, and produced a better result. This happens at a number of levels:

There are two outright mistakes of translation. "Chegueime" is translated as "he came over to me", obviously a hurried reading of a verb which is in fact reflexive, as a straight, direct object, and a lamentable failure to see that the ending of the verb is in the first person; and "Fez-te alguma coisa?" becomes "What did he do?”, which implies that Brás thinks he has done something.
Comparações entre as duas traduções são quase sempre favoráveis a Grossman. Fica claro que a primeira tradução não foi consultada por Rabassa, mas, além disso, parece óbvio que ele não se esforçou muito para solucionar problemas relacionados à língua portuguesa, que são indubitavelmente complexos, mas que, com algum esforço, poderiam ter sido resolvidos e produzido um resultado mais feliz.

Isto acontece em vários níveis:

Há dois erros indiscutíveis de tradução. "Cheguei-me” é traduzido por "he came over to me” [ele chegou até mim], claro que uma leitura apressada de um verbo, que é na verdade reflexivo, como um verbo não-reflexivo, com objeto direto; e num erro primário de português, não consegue ver que a desinência verbal aponta para a primeira pessoa. "Fez-te alguma coisa?” vira "What did he do?", o que implica que Brás acha que ele fez alguma coisa. 
Perhaps the most difficult thing to solve in this short passage is the way of referring to the two people primarily involved, the "whipper" (Prudêncio) and the "whipped" (his nameless slave). This is genuinely difficult, and may even have been so for Machado, who however uses (a) a simple alternation between "o primeiro" and "o outro", and then (b) makes Prudêncio disappear into his whip, so that he becomes "o vergalho" and then "o do vergalho". These are not only grammatical conveniences, ways of keeping the Portuguese concise, they also have thematic implications: they are ways of (a) showing that master and slave are sides of the same coin - "o primeiro" and "o outro", and (b) of depersonifying, or dehumanising Prudêncio, identifying him with his whip. None of this is perhaps obvious, but it is hard to get over in English, and especially in good, natural, tight English: the problems (and Machado's economy) become plain when one looks at the translations. Partly, of course, this has to with Portuguese and English grammar - in the latter, "the one" and "the other" are too undefined, and need at least the addition of "one" ("the other one"). Rabassa has gone for the lazy solution of direct translation: "o outro" becomes "the other one", "o primeiro", the "the first one", and again "o outro", the first one". This has two disadvantages: first, the three words in place of two are clumsy but worse than that, the references in the English become confused. We have "a man whipping another in the square", then “The other one didn't try to run away". Which other one? As the passage proceeds, both problems merely worsen, but this does not seem to worry Rabassa - to go back would mean restructuring, thought and effort. This is the problem that Grossman, by using a little thought or instinct, has solved by using the word "victim". His version loses some of Machado's intensity, and the impersonal
Talvez a questão mais difícil de se resolver neste trecho curto é como se referir às duas pessoas envolvidas, o "chicoteador" (Prudêncio) e o "chicoteado" (escravo sem nome). Isto é francamente complicado e deve ter sido também para Machado, que no entanto usa a) uma simples alternância entre "o primeiro" e "o outro", e então b) faz Prudêncio desaparecer no chicote, virando "o vergalho" e depois “o do vergalho". Estas não são somente conveniências gramaticais ou maneiras de manter a concisão do português, elas têm implicações temáticas: são modos de a) mostrar que senhor e escravo são os dois lados da mesma moeda "o primeiro" e "o outro" e b) de despersonificar ou desumanizar Prudêncio, identificando-o com o chicote. Nada disso é óbvio, mas é difícil transmitir essas nuances em inglês, sobretudo em um inglês bom, natural e coeso - os problemas (e a economia de Machado) ficam evidenciados quando se observa a tradução. Isto tem a ver em parte com a gramática do português e do inglês; neste "the one" e "the other" são muito vagos e precisam pelo menos do acréscimo de "one" ("the first one”, "the other one”). Rabassa optou pela solução mais fácil da tradução direta: "o outro” ficou "the other one", "o primeiro" ficou "the first one" e de novo "o outro" ficou "the other one”. Há duas desvantagens aí: primeiro, a opção por três palavras ao invés de duas incorre em deselegância, mas, mais grave que isso, as referências em inglês ficam confusas. Temos "a man whipping another in the square" [um homem chicoteando outro na praça], em seguida "The other one didn't try to run away" [O outro não tentou fugir]. Qual outro? Com o prosseguimento do texto, ambos problemas só pioram, o que não parece perturbar Rabassa, já que refazer implicaria reestruturação, reflexão e esforço. Esta questão, Grossman resolveu, lançando mão de alguma reflexão ou instinto, usando a palavra "victim" 
way of identifying the two men, the slave and the ex-slave - for both are in a sense "victims", and so it is a pity, though perhaps inevitable, to identify one of them as such - but it is a clear, even an elegant version.

Machado then goes on to a more daring synecdoche, by identifying the whipper with the whip itself "Replicava $o$ vergalho" - finally returning to calling Prudêncio "o do vergalho". Here, both translators have failed, in characteristic ways. Both have used the word "whipper", which to my ears (and those of the spell-check on my computer) sounds awkward, although it does exist in the dictionary. We know what it means, but it is patently a second-best - just as there is no "vergalhador" in Portuguese (just "o vergalho" and "o do vergalho") there should be none in English. Rabassa has "normalised" the "vergalho" by making the "whip" into the "whipper". Grossman omits the phrase "replicava o vergalho" altogether: most likely, given his attitude to Machado's daring - if that is what it is - at other moments, he has simply thought Machado was going too far, making things too strange for the reader. ${ }^{26}$ Yet surely it is not too difficult to get some, though perhaps not all, of the force of Machado's identification of whip and "whipper". "Replied the whip", perhaps? "And down came the whip" if that seems too daring "?

Twice, in the first few lines, Rabassa disrespects Machado's punctuation, turning semi-colons into full stops (these are marked in purple). In both cases this produces a more awkward version - indeed, in one case Rabassa verges on incorrectness: [vítima] para o escravo. A sua versão perde parte da intensidade de Machado e da impessoalidade na identificação dos dois homens, o escravo e o ex-escravo, já que ambos são em certa medida vítimas, o que é uma pena, embora talvez seja inevitável identificar um deles como tal; mas é uma versão facilmente inteligível e mesmo elegante.

Machado então prossegue com uma sinédoque ainda mais audaciosa, identificando o chicoteador com o próprio chicote: "Replicava o vergalho", e por fim voltando a se referir a Prudêncio como "o do vergalho". Neste ponto, ambos tradutores incorreram em falhas típicas. Os dois empregaram "whipper” [chicoteador], que para os meus ouvidos (e para os do revisor ortográfico do meu computador) soa inadequado, embora exista no dicionário. Sabemos o que significa, mas é evidente que há opção melhor. Assim como não tem "vergalhador" em português (apenas "o vergalho" e "o do vergalho") não deveria tampouco existir em inglês. Rabassa naturalizou o "vergalho" transformando "whip" [chicote] em "whipper" [chicoteador]. Grossman omite a frase "replicava o vergalho", provavelmente dado o seu posicionamento diante da ousadia de Machado (se é que é isso mesmo) em outras oportunidades, ele achou que Machado estava indo longe demais, tornando a leitura obscura demais ${ }^{26}$. Contudo, não é impossível passar um pouco, embora não todo, da força de identificação de vergalho e "vergalhador" de Machado. "Replied the whip" [Retrucou o chicote], talvez? "And down came the whip" [E desceu o chicote], se parecer demasiado ousada?

Em duas ocasiões, nas primeiras linhas, Rabassa desrespeita a pontuação de Machado, transformando ponto-evírgulas em pontos (realçados em púrpura). Nos dois casos, isto produz uma versão inadequada; na verdade, em um dos casos, 
"They were interrupted by a gathering of people. It was because of a black man whipping another in the square.” Machado's "Interrompeu-me um ajuntamento; era um preto que vergalhava outro na praça", is economical - one hardly notices that the "ajuntamento" "era" means that the "ajuntamento" is caused by (the scene) of the black man beating another. These shortened phrases - here with a run-on semi-colon - close to the economy of daily speech, are common in Machado, and are, I suspect, one of the most important features of his style. The "It was", and the fullstop in front of it, turns all the economy into awkwardness - the "it", left without a referent, destroys the rhythm. Again, Grossman's version has given some thought to the problem, and produced a harmonious, sensible, result, which conveys all the necessary information, though without the little, insensible jump Machado makes: "My thoughts were interrupted by the sight of a crowd, gathered around a Negro who was whipping another Negro”. Indeed, one word, which may seem to have been forgotten, "na praça" ("in the square"), and which Grossman probably thought would lengthen the sentence too much. However, he has, I think, subtly conveyed the basic information by putting "through" Valongo (unless he has wanted to avoid the awkwardness of "along Valongo", something which plainly failed to impinge on Rabassa's sensibility, or those of his editors), thus implying a space, a square, rather than a street - a typical act of a good translator, faithful in almost unnoticeable ways.
Rabassa beira a incorreção: "They were interrupted by a gathering of people. It was because of a black man whipping another in the square." [Eles foram interrompidos por um ajuntamento de pessoas. Era porque um preto vergalhava outro na praça]. A versão de Machado, "Interrompeu-me um ajuntamento; era um preto que vergalhava outro na praça", é mais econômica - quase não se percebe que "ajuntamento; era" indica que o ajuntamento é causado pelo fato de o negro estar chicoteando o outro. Estas frases reduzidas, nesse caso marcadas com um ponto-e-vírgula, próximas da economia da linguagem cotidiana, em que nem se nota a pequena ousadia gramatical, são correntes em Machado, e são, suspeito, um dos aspectos mais importantes do seu estilo. $\mathrm{O}$ "It was" [era] e o ponto que o antecede transformam a economia em inadequação, o "it”, assim, sem referente, destrói o ritmo. Mais uma vez, Grossman dedicou-se ao problema e produziu um resultado sensato e harmonioso, que transmite toda a informação necessária, embora sem a breve e sutil quebra de Machado: “My thoughts were interrupted by the sight of a crowd, gathered around a Negro who was whipping another Negro” (grifos meus) [Meus pensamentos foram interrompidos pela visão de uma multidão ao redor de um negro, que estava chicoteando outro negro]. As palavras "na praça" [in the square], que podem parecer ter sido esquecidas, Grossman provavelmente achou que estenderia demais o período. Contudo, acredito que ele conseguiu sutilmente transmitir a informação essencial usando "through" Valongo (a menos que sua intenção fosse evitar o desagradável "along Valongo", algo que claramente fugiu à percepção de Rabassa e a dos seus editores), implicando, assim, um espaço, uma praça e não uma rua - um cuidado típico de um bom tradutor, fiel em detalhes quase imperceptíveis. 
In fact, however, the problems do not end here. Machado puts "aquele Valongo" (marked in blue) and the reason is not hard to find. The Valongo was the main Rio de Janeiro slave-market, and so a rather significant place. Given that the translator knows this (and a good, annotated Brazilian edition might tell him), what is he to do about it? ${ }^{27}$ He can't even argue that Machado is not worried about the actual place - otherwise, what is the point of "aquele"? But to put "I walked through the Valongo slave-market" would be too obvious - "aquele" both conveys some of the (hidden or repressed) significance of the place, and of the narrator's reluctance even to look; it is an "effect" of the narration, part of what Machado discovered when he "invented" Brás Cubas as a narrator. In other words, this is a typical case of Machado obliquely referring to something - partly because his narrator is (metaphorically) holding his nose, not anxious to refer to these things directly. No solution here is perfect, simply because our state of knowledge is completely different to that of Machado's reader. But it can't be argued that there is nothing to convey, or even that the loss is a minor one. One answer, and I think the correct one, would be to put a brief note at the bottom of the page (e.g."Valongo: the main Rio slave-market, in the port area"). Neither of these editions uses notes, a decision more understandable in Grossman's case than in Rabassa's, but it is surely a sensible way of making the novel less strange and more pleasurable, so long as it is done in moderation. Oxford University Press, whose lack of elementary care I have already noted, see fit to advertise the fact that my translation of Dom Casmurro is annotated on the cover, and yet did not insist that Rabassa do the same thing.
Os problemas, todavia, não cessam aqui. Machado escreve “aquele Valongo" (realçado em azul) e não é difícil descobrir a razão. O Valongo era o principal mercado de escravos do Rio de Janeiro e portanto um lugar muito significativo. O tradutor tendo conhecimento disso (uma boa edição brasileira anotada o informaria), o que ele deve fazer ${ }^{27}$ Ele não pode nem mesmo argumentar que Machado não está preocupado com o lugar em si - de outra forma, por que "aquele"? Mas optar por "I walked through the Valongo slave-market" [caminhei pelo mercado de escravos do Valongo] seria óbvio demais - "aquele” passa tanto a significância (oculta ou reprimida) do lugar quanto a resistência do narrador até mesmo para olhar; é um "efeito" da narração, parte do que Machado descobriu quando "inventou” Brás Cubas como narrador. Em outras palavras, esta é uma ocorrência típica de Machado se referindo obliquamente a algo - em parte porque o narrador está (metaforicamente) tapando o nariz, não se mostra ansioso por se referir diretamente a estas coisas. Não há solução perfeita para esta questão, simplesmente porque a nossa percepção e os nossos conhecimentos diferem totalmente daquela do leitor do Machado. Mas a argumentação de que não há nada para ser transmitido ou até que a perda é mínima nesse caso não se sustenta. Uma saída, que eu acredito ser a correta, seria adicionar uma nota de pé de página (por exemplo, "Valongo: o principal mercado de escravos do Rio, na zona portuária”). Nenhuma das duas edições usa notas, uma decisão mais compreensível no caso de Grossman que no de Rabassa, mas certamente é uma maneira sensata de tornar o romance menos distante e mais prazeroso, desde que usadas com bom senso. A Oxford University Press, cuja negligência já citei, acha adequado anunciar na capa que a minha tradução de Dom Casmurro é anotada; todavia, não insistiu para 
The infelicities of Rabassa's translation of this short passage don't end here, but five others can be dealt with somewhat summarily (they are marked in grey). (a) his use of "sorry" for "perdão", perfectly adequate in the first context, leads to the quite unnatural (though not impossible) "There's sorry for you". Machado's choice allows for a natural repetition of the word, and also for the brutal irony that Prudêncio is dispensing "pardon". Grossman has thought a little, and produced an equally natural "mercy", which carries all the effect of the original. (b) "cala a boca, besta!": a minor detail perhaps, but this phrase, so expressive of insouciant cruelty, should surely be repeated word for word from Chapter 11, where it is first said by Brás as he "rides" his young slave. Rabassa has, in the first case "Shut your mouth, you animal!”, then, here "Shut your mouth, animal!” (Grossman's "beast" is also better, because shorter). This is something a good editor ought to have picked up as well. (c) "uma nova vergalhada" is "a new lash of the whip", not "a new lashing", which implies several lashes. This is just a question of accuracy. (d) "pediu-me a bênção": here Grossman shows an admirable knowledge of Brazilian customs - "tomar a bênção", according to the Houaiss dictionary means primarily "beijar a mão de (alguém) ou o anel de (um prelado)...”. It was highly significant gesture (for example, it was sign of the Emperor's superiority to his subjects, and quickly abolished when the Republic came into existence, and many Brazilians still remember the times when they asked a "blessing" of their parents, kissing their hands), and shows that Prudêncio, though "free" still owes obedience to his (ex-)master. Not an important mistake on Rabassa's part maybe, but still a mistake, and a real indication of some of the care and quality of Grossman's que Rabassa fizesse o mesmo.

As infelicidades da tradução de Rabassa deste curto trecho não acabam por aqui, mas outras cinco podem ser examinadas de forma sintética (realçadas em cinza). a) o emprego de "sorry" para "perdão", perfeitamente adequado no primeiro contexto, gera o bastante artificial (embora não impossível) "There's sorry for you”. A opção de Machado permite uma repetição natural da palavra e igualmente a ironia brutal que Prudêncio está administrando "perdão". Grossman ponderou um pouco e o resultado foi o igualmente natural "mercy", que produz todo o efeito do original. b) "cala a boca, besta!": um detalhe menor talvez, mas esta frase, tão carregada de crueldade despreocupada, deveria ser repetida palavra por palavra do capítulo 11, onde é dita pela primeira vez por Brás quando ele "monta" seu jovem escravo: também é a maior evidência que Prudêncio está se vingando do seu passado. Rabassa optou na primeira vez por "Shut your mouth, you animal!", depois, no trecho em questão, "Shut your mouth, animal!” ("beast”, usado por Grossman é melhor por ser mais curto). Este é um detalhe que um bom editor deveria ter percebido. c) "uma nova vergalhada" corresponde a "a new lash of the whip" e não "a new lashing”, o que implica uma série de chicotadas. Esta é apenas uma questão de precisão. d) Em "pediu-me a bênção", Grossman demonstra um conhecimento admirável dos costumes brasileiros - "tomar a bênção”, de acordo com o dicionário Houaiss, significa primeiramente "beijar a mão de (alguém) ou o anel de (um prelado)...”. Era um gesto extremamente significativo (representava, por exemplo, a superioridade do Imperador em relação aos súditos e foi rapidamente abolido quando surgiu a República, e muitas pessoas ainda hoje se lembram dos tempos em 
version. (e) "nhonhô" - Grossman’s choice to keep the original word might look like a case of laziness, but, when one looks at the alternatives - including Rabassa's "little master" - it looks more understandable. To put a note here would surely be over-egging the pudding; the sound, and even the aspect of the word conveys something of its humiliating "childishness", which intentionally takes us back to Chapter 11; and in fact he justifies his choice in a short explanatory note to the edition I have. ${ }^{28}$

This analysis leads us in two directions - first, to a characterisation of the failures of Rabassa's translation, and, by reverse implication, to some of the qualities a good translator ought to have. This can be done in a short space.

The first serious mistake that Rabassa seems to me to have made is to ignore his predecessor - a deliberate move, of course, perhaps motivated by the fear of not being thought original. ${ }^{29}$ Berman seems to me to be right - in fact, it is almost a matter of common sense - that earlier versions should be consulted, even if only their solutions are rejected. At the very least, they can save us from mistakes; sometimes, even if we don't adopt their solutions, the process of thinking about them can lead to another, third, and better solution; translating can be a very solitary process, and any perspectives we can open on our own thought-processes should be welcome. My solution with Dom Casmurro was to carefully translate a longish stretch (in other words, think everything through and produce a version I thought publishable) - between five and ten chapters - then leave it for a que se pedia bênção aos pais, beijando a mão deles) e indica que Prudêncio, embora "forro" ainda deve obediência ao seu (ex)senhor. Talvez não seja um erro grave de Rabassa, mas é um erro e uma indicação real do cuidado e da qualidade da versão de Grossman. e) A opção de Grossman de manter "nhonhô" na sua tradução pode parecer preguiça, mas, quando se pensa nas alternativas - incluindo a "little master" de Rabassa - parece mais compreensível. Acrescentar uma nota aí seria pecar por excesso; o som e até mesmo o aspecto da palavra transmitem algo da "infantilidade" humilhante, o que nos leva intencionalmente ao capítulo 11, e de fato ele justifica a sua escolha numa curta nota explicativa à p. 14, no fim da introdução da edição que possuo. ${ }^{28}$

Esta análise aponta em duas direções, que podem ser abordadas com alguma brevidade: primeiro, uma caracterização das falhas na tradução de Rabassa e, na direção contrária, algumas qualidades de uma boa tradução.

O primeiro erro grave que Rabassa, ao meu ver, parece ter cometido foi desconsiderar seu predecessor - um ato deliberado, claro, talvez motivado pelo medo de não parecer original. ${ }^{29}$ É quase uma questão de bom senso que versões anteriores devem ser consultadas, mesmo que para rejeitar as suas soluções. Elas podem, no mínimo, nos livrar de erros; algumas vezes, mesmo quando não adotamos as soluções dadas, o processo de pensar sobre elas pode nos levar a uma solução diferente e melhor; a tradução pode ser um processo bastante solitário, e qualquer perspectiva nova que se abre nesse processo reflexivo deve ser bem-vinda. Meu procedimento com Dom Casmurro foi o de traduzir atentamente um trecho um pouco mais extenso, de cinco a dez capítulos, (ou seja, atentar para tudo e produzir uma versão que eu considerasse publicável) deixá-lo então por algum tempo, 
while, then come back, look at both the earlier versions, think, adjust, and finally leave the section till later, and move on to the next one.

The reasons behind the common sense of this procedure are, fundamentally, that one's primary duty is to the original, and that other people's versions can almost always help towards improvement, since everyone makes mistakes, and everyone's reach, even with the help of dictionaries and thesauruses, is limited; as I hope I have just shown, even a bad translation can tell us something about the original. If I were to retranslate Memórias póstumas, I would use Rabassa's version and Grossman's (even Ellis's), though with “distâncias guardadas”, naturally. This basic mistake seems to spring from a certain over-confidence on Rabassa's part, also witnessed in the fact that he somewhat proudly tells us that when he is translating a living author, he doesn't consult him - if that's what's meant by the statement that "I only met Mário once", when he writes about Mário de Carvalho's Um deus passeando pela brisa da $\operatorname{tarde} e^{30}$, and by other commentaries in the same book.

However, the main conclusion must be that Machado must not be translated in a hurry, or lazily - this might seem an obvious fact, but having seen the many layers of mistakes that laziness and lack of care can lead to, I have come to the conclusion that it is the most important one; the only other explanation is an extraordinary lack of sensitivity to the original and to the English language, which is highly unlikely. It may seem unfair to group everything else under the rubric of laziness, but the typos, the grammatical mistakes, the inaccuracies, the failure to produce a fluent English version when the Portuguese presents difficulties, depois retomá-lo, ler as duas versões anteriores, refletir, ajustar e, por fim, prosseguir para um novo trecho.

As razões que justificam o senso prático deste método são, antes de mais nada, que a primeira preocupação do tradutor deve ser com o original e que outras versões são quase sempre úteis no processo da busca, uma vez que erros são comuns a todos e o alcance do tradutor, mesmo com a ajuda de dicionários, monolíngüe, bilíngüe ou de sinônimos, é limitado; como espero ter mostrado, até mesmo uma tradução ruim pode nos dizer algo sobre o original. Se eu propusesse uma nova tradução para as Memórias póstumas, consultaria as versões de Rabassa e de Grossman (até a de Ellis), com distâncias guardadas, naturalmente. Este erro primário parece proceder de uma certa confiança excessiva de Rabassa, também atestado no fato de que ele, com certo orgulho, afirma que quando traduz um autor vivo, não o consulta - se é o que se pode deduzir da declaração "só encontrei Mário uma vez", quando escreve sobre Um deus passeando pela brisa da tarde $e^{30}$ do romancista português Mário de Carvalho e de outros comentários no seu livro de memórias, If this be Treason [Se for traição] .

Contudo, a principal conclusão é que Machado não deve ser traduzido com precipitação nem com preguiça, o que pode parecer óbvio, mas em vista dos vários níveis de erros que a preguiça e o descaso podem causar, cheguei à conclusão que essa é a mais importante; a única outra explicação é uma extraordinária ausência de identificação com o original e com a língua inglesa, o que é bastante improvável. Pode parecer parcial agrupar tudo sob a rubrica da preguiça, mas os erros tipográficos, os de gramática, as imprecisões, o insucesso na produção de uma versão fluente em inglês diante das dificuldades do original em português, o 
the lack of respect for Machado's punctuation, the lack of notes, all seem to point to this one source, in this case compounded by the publishers' irresponsibility, delighted as they no doubt were to be publishing a classic author out of copyright.

Translators are paid by the word (or, in Brazil, by the "toque"), and not by time spent. The obvious temptation is to do as much as possible in as short a time as possible. Rabassa, in particular, has translated a great deal, both from Spanish and Portuguese, books of very varying degrees and types of difficulty. Quite probably, too, he has achieved differing degrees of success, as is not unusual with translators. ${ }^{31}$

I had just reached this somewhat reluctant conclusion, when I found confirmation of it from the most improbable of sources, Rabassa himself, who, on p. 27 of the memoir quoted earlier, If this be Treason, admits to this same failing. He talks about his "inherent laziness and impatience", while on the subject of Cortázar's Rayuela. Obviously, to him it is part of the offhand manner the reader is supposed to find charming, and brings "freshness" to his work. If there is one lesson to be learned from his translation of Machado, it is that it doesn't work in the case of the great Brazilian novelist.

What is it about Machado's prose that means that it is not amenable to the "lazy" theory of translation? If the question seems sarcastic, that is not the intention: what we have seen is a type of construction so tight, in which every word is thought out, no more words are used than necessary, which in itself poses a challenge to the translator. Roberto Schwarz, in the opening pages of Um mestre na periferia do capitalismo, says the following: desrespeito com a pontuação de Machado, a ausência de notas, tudo isso parece apontar para uma fonte, neste caso combinada à irresponsabilidade das editoras, satisfeitas, sem dúvida, de publicarem um autor clássico cuja obra caiu em domínio público.

Os tradutores são pagos por palavra (ou, no Brasil, por toque) e não por hora. A tentação óbvia é produzir o máximo possível no menor espaço de tempo. Rabassa, em especial, traduziu bastante, tanto do espanhol quanto do português, sua produção abrange textos de graus e tipos de dificuldade dos mais variados. É provável também que ele tenha atingido graus diversos de êxito na tradução, o que não é raro para os tradutores ${ }^{31}$.

Apenas chegara a essa conclusão um tanto hesitante quando a confirmei na fonte mais improvável, o próprio Rabassa, que, à página 27 da mesma autobiografia mencionada, If this be Treason, admite essa falha. Ele fala da sua "preguiça e impaciência inerentes” quando se refere ao Rayuela de Cortázar. É evidente que para ele isso faz parte da informalidade, que o leitor supostamente acha encantadora e confere leveza ao seu trabalho; em última instância, do seu gênio como tradutor. Se há alguma lição a ser tirada da sua tradução de Machado é que aquela estratégia não funciona no caso do maior romancista brasileiro.

O que há na narrativa de Machado que resiste à teoria "preguiçosa” de tradução? Se a pergunta soa sarcástica, não é essa a intenção. O que se vê é um tipo tão coeso de construção, em que cada palavra é ponderada e somente são usadas as palavras necessárias, que, em si, já constitui um desafio para o tradutor. Roberto Schwarz, nas primeiras páginas de Um mestre na periferia do capitalismo, escreve: 
In Machado's novels there is hardly a phrase that doesn't have a second meaning or witty intention. His prose pays extreme attention to detail, and is always on the lookout for immediate effects: this ties the reader down to the minutiae and makes it difficult to picture the wider panorama. (my emphasis) ${ }^{32}$

This gives some idea of what the careful translator faces, for s/he has to keep his/her sights on both levels, the immediate and the larger issues. On a somewhat higher level of generality, Roberto Schwarz, in the preface to the same book, says that "(...) Machado's narrative prose is one of the very few that, simply in their movement, constitute a complex socio-historical spectacle, of the greatest interest, and in which the surface subject is of little moment. In this respect, comparisons could be made with the prose of Chateaubriand, Henry James, Marcel Proust or Thomas Mann". ${ }^{33}$ What the above analysis of the two translations of Brás Cubas does, I think, is show some of this in practice, to demonstrate the "attention to detail", and make one think again, perhaps with a little better idea of the nature of the mountain to be climbed. Seeing the mistakes (and the successes) of other translations is an excellent way of appreciating the original, and even of seeing some of the choices Machado made. There is a real sense in which one is closer to choices Machado perhaps made, and his intentions.

To take the argument one step further, I now want to look at my own translation of Dom Casmurro. In translation, it is often easier to criticise than to justify one's own solutions: as one progresses to this stage, too, the limitations imposed by the language being translated into (the target-language, as it is usually called in translation theory) come further into view. This can be
No romance machadiano praticamente não há frase que não tenha segunda intenção ou propósito espirituoso. A prosa é detalhista ao extremo, sempre à cata de efeitos imediatos, o que amarra a leitura ao pormenor e dificulta a imaginação do panorama. (grifo meu) ${ }^{32}$

Isto dá uma idéia do que o tradutor cuidadoso enfrenta, pois ele tem que atentar para ambos níveis, os efeitos imediatos e os mais amplos. Em um nível mais alto de generalidade, no prefácio do mesmo livro, Schwarz diz que “(...) a prosa narrativa machadiana é das raríssimas que pelo seu mero movimento constituem um espetáculo histórico-social complexo, do mais alto interesse, importando pouco o assunto de primeiro plano. Neste aspecto caberiam comparações com a prosa de Chateaubriand, Henry James, Marcel Proust ou Thomas Mann”. ${ }^{33}$ Para usar uma expressão schwarziana, o que a nossa análise das duas traduções de Brás Cubas faz, acho, é "trocar em miúdos" alguns detalhes, demonstrar o "detalhismo" e fazer com que se repense, talvez com uma idéia mais precisa da natureza da montanha a ser escalada. Perceber erros e acertos de outras traduções é uma excelente maneira de apreciar o original e até mesmo de considerar algumas das opções de Machado. Existe um sentido real no qual se fica mais próximo das opções de Machado e das suas intenções.

Para avançar mais na argumentação, farei um exame da minha própria tradução de Dom Casmurro. Em tradução, muitas vezes é mais fácil criticar que justificar as próprias escolhas. Com o avanço desse processo, também, as limitações impostas pela língua para a qual se traduz (a língua alvo, como normalmente é chamada na teoria da tradução) ficam mais patentes. Isto pode ser 
seen most clearly, perhaps, by comparing translations into languages closer to Portuguese, where translators are less often asked to make hard choices. The features of the original, and above all Machado's economy and prose rhythm, are no less evident. Again, I can only demonstrate this in a short passage, and have chosen one that constitutes an entire chapter, and not a particularly famous one, Chapter 28, "Na rua". It has the advantage of dealing with character - that of José Dias, in this case - and character in action, one of the fields in which Machado's subtlety, and his prose rhythm, always pose problems to the translator. For ease of reading, and of seeing the chapter as a whole, I have distributed the four passages horizontally. They are, in (chronological) order: the original, Caldwell, Scott-Buccleuch, and my own:

José Dias ia tão contente que trocou o homem dos momentos graves, como era à rua, pelo homem dobradiço e inquieto. Mexia-se todo, falava de tudo, fazia-me parar a cada passo diante de um mostrador ou um cartaz de teatro. Contava-me o enredo de algumas peças, recitava monólogos em verso. Fez os recados todos, pagou contas, recebeu aluguéis de casa; para si comprou

Afinal, o
José Dias was so content that he changed from the man of graver moments, such as he was in public, to the springy, restless man. He waved his arms and legs, spoke of everything, made me stop before every shop display or theater bill. He told me the plot of several plays, recited monologues in verse, did all his errands, paid accounts, collected rents; for himself he bought visto com maior clareza, talvez, pelo cotejo de traduções para línguas mais próximas do português, nas quais os tradutores se vêem diante de escolhas difíceis com uma freqüência menor. As características do original e, acima de tudo, a economia e o ritmo narrativo de Machado ficam evidenciados. Mais uma vez, demonstrarei isso mediante análise de um trecho; escolho um capítulo inteiro, curto e não particularmente famoso, o 28, "Na rua”. Ele tem a vantagem de lidar com um personagem - José Dias, nesse caso - e personagem em ação, um dos campos em que a sutileza e o ritmo narrativo de Machado sempre apresentam dificuldades para o tradutor. Para facilitar a leitura e visualizar o capítulo inteiro, exporei os quatro trechos horizontalmente. Eles estão dispostos na ordem cronológica, ou seja, o original, e as versões de Caldwell, de Scott-Buccleuch e a minha.
José Dias was so pleased with himself that his manner changed completely: normally composed in the street, he was now nervous and preoccupied. Restless and talkative, he made me stop in front of every notice-board or theatre bill. He told me the plot of various plays, reciting some of the monologues in verse. $\mathrm{He}$ attended to all his business, paid bills and collected the rent from the tenants; for himself he
José Dias was so happy that the gravity which was his usual manner in the street gave way to his elastic, restless demeanour. Gesticulating and talking a great deal, he made me stop over and over again at shop windows or theatre bills. He recounted the plot of some of the plays and recited monologues in verse. He did all his errands, paid bills, collected rents; for himself he bought a Finally the 
homem teso rendeu o flexível, e passou a falar pausado, com superlativos. Não via que a mudança era natural; temi que houvesse mudado a resolução assentada, e entrei a tratá-lo com palavras e gestos carinhosos, até entrarmos no ônibus. tense man drove out the volatile, and he reverted to his slow, deliberate speech, with the superlatives. I did not see that the change was natural; I was afraid that he had changed his mind, and I tried to ingratiate myself by affectionate words and gestures, until we boarded the omnibus.

To do justice to all the issues and decisions present even in this short passage and its three translations is not easy - much more difficult, in fact, than identifying and categorising the mistakes in Rabassa's translation of Memórias póstumas de Brás Cubas. Here, to begin with, there are no "mistakes". There are choices, some of them better than others of course, but which have degrees of rightness and wrongness - sometimes close to outright mistakes, in fact, as we will see. What is more, one choice often reflects on another, so that each passage needs to be seen as a system - not only that, of course, but each has to be seen as forming part of the wider whole that is the novel itself; even looking at the uses of a word in other novels can help. ${ }^{34}$ Having said that, I will now try to identify some of the issues present here,

bought a twentieth share of a
lottery ticket. Finally, his natural gravity vanquished his present levity, and he began to speak with greater deliberation, using the customary this was a natural transformation, I was afraid he had gone back on our agreement, and addressed him with ingratiating words and gestures until we got into the bus. superlatives. Not realising that finally, formality carried the day over flexibility, and he began to talk with deliberation again, using his usual superlatives. I didn't see that this was a natural change; I was afraid that he might have changed his mind, and began to treat him with affectionate words and gestures, until we got back on the bus.
Expor todas as questões e decisões presentes neste breve trecho e nas suas três traduções não é tarefa fácil; muito mais difícil, na verdade, que identificar e classificar os erros na tradução de Memórias póstumas de Brás Cubas de Rabassa. Para começar, não há "erros” aqui, e sim escolhas, algumas melhores que outras, mas com graus de exatidão e inexatidão - beirando, de fato, em erro mesmo, como veremos em alguns casos. Além disso, uma escolha com freqüência implica outra, de tal modo que cada trecho deve ser visto como um sistema - não apenas isso, mas cada um deles deve ser visto como uma porção de um todo maior, o romance em si; até mesmo a observação dos usos de uma palavra em outros romances pode ser útil. ${ }^{34}$ Feitas estas considerações, passo então à tentativa de identificação de algumas das questões

Scientia Traductionis, n.14, 2013 
of rhythm, style and meaning. I should perhaps say that I find it impossible to remember the process of choice when I was translating, and so when I say "I was surprised", I mean that I was surprised now, in the process of analysing the passages for this essay. I should also say that, although (obviously) I think my translation is the best, there is still room for improvement.

A good part of the difficulty of translating this short chapter lies in the adjectives. Since adjectives qualify nouns, they often carry nuances, and so can be difficult to translate, since many adjectives, perhaps more than other parts of speech, cover an "area" of meaning, and the areas covered by equivalent words rarely coincide completely. Anyone with a minimum of knowledge and appreciation of Machado's prose will know how important adjectives are - look at the role the words "olhos de cigana oblíqua e dissimulada" play in Dom Casmurro, and in fact how the adjectives, in the passage where Bento looks at Capitu's eyes, float apparently "free" from the noun which nevertheless colours them.

The classic moment when Machado mentions the part of speech is in Memórias póstumas de Brás Cubas, and the passage is a very interesting one: "Se o leitor ainda se lembra do capítulo XXIII, observará que é agora a segunda vez que eu comparo a vida a um enxurro; mas também há de reparar que desta vez acrescentolhe um adjetivo - perpétuo. E Deus sabe a força de um adjetivo, principalmente em países novos e cálidos." The adjective "perpétuo" here is almost empty of meaning, since the phrase "a vida é um enxurro" is hardly less (or more) meaningful than the same phrase with the adjective added, but its purely rhetorical aqui presentes, a saber, ritmo, estilo e significado. Devo talvez acrescentar que acredito ser impossível lembrar o processo de escolha enquanto eu traduzia; logo, quando digo que "fiquei surpreso", refiro-me à surpresa atual, no processo de análise dos trechos para este ensaio. Devo dizer também que embora considere (obviamente) minha tradução a melhor, ela ainda pode ser melhorada.

Boa parte da dificuldade da tradução deste capitulozinho, no medida em que existe, tem a ver com os adjetivos. Como estes qualificam os substantivos, apresentam matizes que podem dificultar a tradução, uma vez que muitos adjetivos, talvez mais que outras classes de palavras, cobrem uma "área” um tanto movediça de significado, e as áreas cobertas por vocábulos equivalentes raramente coincidem. Qualquer um com o mínimo de conhecimento e gosto pela narrativa de Machado sabe da importância dos adjetivos ali - lembre-se do papel que os "olhos de cigana oblíqua e dissimulada” desempenham em Dom Casmurro e como os adjetivos, na passagem em que Bento olha os olhos de Capitu, flutuam aparentemente "livres" do substantivo que não obstante os colore.

O momento clássico em que Machado menciona esta classe de palavras é em um trecho muito interessante de Memórias póstumas de Brás Cubas: "Se o leitor ainda se lembra do capítulo XXIII, observará que é agora a segunda vez que eu comparo a vida a um enxurro; mas também há de reparar que desta vez acrescentolhe um adjetivo - perpétuo. E Deus sabe a força de um adjetivo, principalmente em países novos e cálidos.” O adjetivo "perpétuo" nesse caso é quase vazio de significado, já que a frase "a vida é um enxurro" não adquire mais (nem menos) significado com a adição do adjetivo, mas sua força puramente retórica existe e viceja no 
power exists and flourishes, in the Brazilian "climate". The adjective, then, is one of the places where the contradictory impulses of Machado's prose, the extreme attention to detail, and the wider panorama, as described by Roberto Schwarz, meet.

The six words highlighted in yellow all refer to José Dias, and in the original are adjectives: contente, graves, dobradiço, inquieto, teso, flexível. They can be dealt with under a few different rubrics, according the type of problem they involve:

(a) Only one of these, "contente" could be called easy to translate, and even then I was surprised to find that the three translations are different - "content", "pleased with himself", "happy". In a sense each is typical of its translator. Caldwell tends to stick quite close to the original (in Patai's words, already quoted, to be "somewhat in thrall to the original language") and perhaps to be a little "Latinate" in her choices. Scott-Buccleuch will quite readily stray from the original (here in "pleased with himself", which is not quite accurate, for he is in fact pleased with the prospect of an expenses-paid trip to Europe), in ways that seem trivial; in fact, the slight distortions accumulate and give a wrong picture. I tend to be very aware of the choices posed by the common "Germanic"/ "Latinate" oppositions in English, and often go for the "Germanic" words, because they are more colloquial, and Bento's tone is, I think, intended to be familiar, with a rhythmic basis in common speech, though with a patina of formality and old-fashionedness in it, as suits Dom Casmurro with his legalistic mind and his "fumos de fidalgo". At the very least, that colloquial feeling should be present in an unobtrusive way, as it is in the original. "clima” brasileiro. O adjetivo é, pois, um dos lugares onde os impulsos contraditórios, o "detalhismo" e a "imaginação do panorama" da narrativa de Machado, como bem descritos por Roberto Schwarz, se encontram.

As seis palavras realçadas em amarelo referem-se a José Dias e são originalmente adjetivos, a saber, contente, graves, dobradiço, inquieto, teso e flexível. Eles podem ser analisados sob rubricas diversas, levando em consideração as dificuldades que apresentam:

Apenas um deles, o “contente”, pode ser considerado fácil de traduzir e, mesmo nesse caso, fiquei surpreso em descobrir que as três traduções apresentam soluções diferentes: “content" [contente], "pleased with himself" [satisfeito com ele mesmo] e "happy" [feliz]. De certo modo, cada solução é típica do tradutor que a adotou. Caldwell tende a se prender ao original (de acordo com Patai, já citada, a ficar "um pouco submissa à língua original") e, talvez como conseqüência, a "latinar" suas escolhas. Scott-Buccleuch desvia-se do original sem que isso pareça preocupar-lhe demais (nesse caso, "satisfeito com ele mesmo ", que não é exato, já que ele está na verdade satisfeito com a perspectiva de uma viagem com todas as despesas pagas para a Europa) em detalhes que parecem triviais; na verdade, os leves desvios se acumulam e desvirtuam a cena. Por mim, procuro ficar consciente das escolhas propostas pela oposição, no inglês, entre palavras de origem germânica e as de origem latina. Com freqüência, opto pelas de origem germânica porque são mais coloquiais e, acho, o tom de Bento se pretende familiar, com uma base rítmica no discurso cotidiano, embora com um verniz de formalidade e arcaísmo, como convém a Dom Casmurro com sua mente legalista e seus "fumos de fidalgo". No mínimo, essa 
(b) "grave" is more difficult than it seems. The obvious equivalent (identical) word "grave" will often not do, because its colouring is more serious and less latent with ironic possibilities than the Portuguese, perhaps because of the proximity of the noun "grave". French and Spanish do not have this problem. The word is in fact associated with José Dias, right from the first description of him, where he is said to be "Nos lances graves, gravíssimo" (cap. 5). More generally, it is often associated with hypocrisy. In chapter 93, Escobar calls Dona Glória "senhora grave, distinta e moça" - here, the irony reflects both on the speaker and the subject, Dona Glória. A frequent option, which is commoner and more easily carries some of the irony, is "serious", used by all three translators at one moment or another. Both Caldwell and I have decided to "hide" the word to an extent, she by making it comparative, and I by making it a noun, "gravity", which I hope will remove some of the "seriousness" threatening the word in English. Caldwell in fact uses "grave" to translate the phrase quoted from Chapter 5: "In grave situations, most grave gravissimo", an ingenious solution in fact, playing on the musical connotations in English of the -issimo ending (fortissimo, pianissimo), and getting some of the force of the Latinate superlative in English; though its effect is reduced by the fact that it cannot be carried through, at all the points in the novel where the superlatives recur. At that point, I went for "serious", and for a (repeatable) "most" - "At serious moments, most serious". "Composed", which is Scott-Buccleuch's solution, seems too far from the central meaning of the Portuguese to be satisfactory - we will see in a moment why he may have been forced to stray. sensação de coloquialidade deveria estar presente de maneira discreta, a exemplo do original.

O "grave" é mais complexo que parece. O equivalente óbvio (idêntico) em inglês, "grave”, não funciona porque apresenta um matiz mais sério e possui menos possibilidades irônicas embutidas que em português, talvez pelo seu homônimo, o substantivo "grave" [túmulo]. Nem o espanhol nem o francês apresentam este problema. O vocábulo está associado a José Dias desde a primeira descrição dele, quando é apresentado como sendo "Nos lances graves, gravíssimo" (cap. 5). De uma maneira mais geral, é (frequentemente) associado à hipocrisia. No capítulo 93, Escobar refere-se a Dona Glória como "senhora grave, distinta e moça" - a ironia aqui se refere tanto ao falante quanto ao assunto, Dona Glória. Uma opção freqüente, mais comum e que transmite alguma ironia, é "serious" [séria], empregada pelos três tradutores em determinado momento. Tanto Caldwell quanto eu decidimos "ocultar" o vocábulo até certo ponto; ela, transformando-o em comparativo, eu, em substantivo, "gravity” [gravidade], com que espero suprimir parte da "seriedade" que o ameaça em inglês. Caldwell, na verdade, emprega "grave” na tradução da frase já citada do capítulo 5: "In grave situations, most grave gravissimo”, solução engenhosa, jogando com a conotação musical do sufixo issimo em inglês (fortissimo, pianissimo) e transmitindo parte da força do superlativo de eco latino para o inglês; contudo, tem o seu efeito reduzido por não poder ser empregado em todas as (muitas) ocorrências de superlativos ao longo do romance. No mesmo trecho, optei por "serious" e por um (repetível) "most": "At serious moments, most serious." "Composed”[calmo], solução de Scott-Buccleuch, parece distante demais do significado principal em português para funcionar - veremos em breve o 
(c) The other four adjectives, "dobradiço", "inquieto", "teso", and "flexível" can be dealt with in common: they are all descriptive of the agregado's manner, and "dobradiço", "teso" and "flexível" are all variations on the theme of stiffness and flexibility. A short search in the texts of the novels backs up this view in a way that is surprisingly absolute and conclusive, as if two of the adjectives had (in Machado's mind) no other real application, and were limited to this "sphere". None of these three appear elsewhere in Dom Casmurro. The first two, "dobradiço" and "teso" have very limited applications in all the rest of the novels, and are always associated with servility - either that of an actual servant, or of a parasite. "Dobradiço", not a common adjective, is plainly a variant of "flexible" - as a feminine noun, it means a hinge, and is in fact used this way in Memórias póstumas de Brás Cubas. Its only appearance in the novels, in Ressurreição (Ch. 1, I, p. 118), is in a description of a parasite, Viana, "parasita da consideração e da amizade", "um desses homens metediços e dobradiços que vão a toda a parte e conhecem todas as pessoas". "Teso", in its turn, only appears in Quincas Borba, where, significantly, it is associated not only with stiffness, but with the stiffness of servility, twice out of three times with an actual servant: "O criado esperava, teso e grave" (Ch. 3), and "Teso, descoberto, o lacaio..." (Ch. 150), and the other with the parasite Freitas: "colou-se ao espaldar, teso, grave, olhando para um painel da parede..." (Ch. 31). "Flexível", a much more common adjective, is applied to other things, notably to the figures of Virgília and Fidélia. "Inquieto", not surprisingly, is more common still, and varied in its applications. porquê de ele poder ter sido forçado ao desvio.

Os outros quatro adjetivos, a saber, "dobradiço", "inquieto", "teso" e "flexível”, podem ser examinados em conjunto, pois todos são descritivos do comportamento do agregado, e "dobradiço", "teso" e "flexível” são variações de rigidez e maleabilidade. Um breve exame dos textos dos romances reforça esta idéia de uma maneira admiravelmente absoluta e conclusiva, como se dois dos adjetivos (para Machado) não tivessem nenhuma outra aplicação real e estivessem limitados a esta esfera. Nenhum destes três reaparece em Dom Casmurro. Os dois primeiros, "dobradiço" e "teso", têm aplicações muito limitadas no restante dos romances e estão sempre associados à servidão ou servilismo, tanto a de um criado de fato quanto a de um parasita. "Dobradiço", que não é um adjetivo muito comum, nada mais é senão uma variante de "flexível" - como um substantivo feminino, significa charneira e de fato é assim empregado em Memórias póstumas de Brás Cubas. A sua única ocorrência nos romances, em Ressurreição (cap. 1, I, p. 118), deve-se à descrição de um parasita, Viana, "parasita da consideração e da amizade", "um desses homens metediços e dobradiços que vão a toda parte e conhecem todas as pessoas". “Teso", por seu turno, aparece somente em Quincas Borba, onde significantemente está associado não apenas à rigidez, mas à rigidez da servidão, em duas das três vezes a um criado de fato: "O criado esperava, teso e grave" (cap. 3), e "Teso, descoberto, o lacaio..." (cap. 150); a terceira ao parasita Freitas: "colou-se ao espaldar, teso, grave, olhando para um painel da parede...” (cap. 31). "Flexível", adjetivo mais comum, tem outras aplicações, notadamente, às figuras de Virgília e Fidélia. "Inquieto”, como é de se esperar, é ainda mais comum e tem aplicações mais variadas. 
Having some notion how to translate these adjectives depends in good part on understanding the character of the agregado: the basic description is given in Chapters 4 and 5 as stiff and slow ("calculado e deduzido"), but also agile and quickmoving ("rápido e lépido"), "tão natural [be it noted] nesta como naquela maneira" ("as natural in one mode as in the other"). These contradictions do not so much imply hypocrisy itself as an ingrained falsity, now almost natural to him, and caused by his ambiguous status in the household. That is why Machado uses the unusual word "acionados" to describe his gestures, in this same passage - the word is defined by the Houaiss dictionary as "gesticulação de quem fala ou representa".

Returning, finally, to the translations, "dobradiço" has been rendered by each translator very differently: in order, "springy", "nervous”, and “elastic”. The Taylor Dictionary gives "flexible" as the first meaning, and it can be seen that, given that "flexible" appears four lines later, Caldwell and I have been forced to try to find synonyms, aware too perhaps that "dobradiço" itself is a much more unusual word. Scott-Buccleuch, it seems, has given up, and uses a word which is nothing to do with the case, as is not infrequent with him. He is, unsurprisingly, the translator who least understands the agregado, translating the very word as "a friend of the family". I think that my solution is better here, because it conveys the fact that José Dias "bends" or "folds" (dobra), adjusts himself to whatever forces are operating - it may be that "springy" was intended to do that, by the relation with "spring" ("mola"), but if it was, I doubt it has achieved its aim. Again, in translating "inquieto", Caldwell and I agree on the simple "restless", while Scott-Buccleuch, in a chapter peppered with difficult adjectives, forces two more on himself by translating
A noção de como traduzir estes adjetivos depende em grande parte da compreensão do caráter do agregado. Sua primeira descrição é apresentada nos capítulos 4 e 5 como "calculado e deduzido", mas também "rápido e lépido", "tão natural [note-se bem] nesta como naquela maneira”. Estas contradições não estão tão associadas à hipocrisia em si quanto a uma falsidade arraigada, então quase natural a ele, causada pelo seu status ambíguo na família. Daí Machado empregar o incomum “acionados” para descrever-lhe os gestos no mesmo trecho. A palavra é definida pelo dicionário Houaiss como "gesticulação de quem fala ou representa (grifo meu)".

Retomando, por fim, as traduções, "dobradiço" teve três soluções bastante diferentes entre si: na ordem, "springy" [resiliente], "nervous” [nervoso] e "elastic” [elástico]. O dicionário bilíngüe Taylor traz "flexível” como primeiro significado ${ }^{35}$ e, como "flexível" aparece quatro linhas abaixo, pode-se perceber que eu e Caldwell nos vimos forçados a buscar sinônimos, talvez conscientes de que "dobradiço" seja uma palavra muito menos freqüente. Scott-Buccleuch, ao que parece, desiste e emprega uma palavra que não tem relação com a circunstância, o que acontece com alguma freqüência no seu texto. Ele é o tradutor que menos compreende a idéia de agregado, traduzindo a palavra por "a friend of the family" [amigo da família]. Acredito que a minha solução seja melhor, pois transmite o fato de que José Dias se curva ou se dobra, ajustando-se a quaisquer forças vigentes - pode ser que a intenção com "springy" fosse essa, pela relação com "spring" [mola], mas se foi isso mesmo, não acho que tenha provocado o efeito pretendido. Mais uma vez, com "inquieto", eu e Caldwell concordamos com o simples "restless" [desassossegado]; ao passo 
the two following verbs "Mexia-se todo, falava de tudo", as "Restless and talkative". The result is another extraneous adjective for "inquieto", "preoccupied", which is "inquieto" in the sense of "worried", not "unquiet", almost in the sense of the Portuguese "irrequieto", surely the meaning here.

When we come to the final two opposed adjectives, "teso" and "flexível", we can see that Caldwell, in her turn, has misunderstood "teso" by translating it as "tense" - the first word in the Taylor dictionary, but which refers us to the wrong semantic area, of psychological tension, which has nothing to do with the case; she fails to see it as connoting rather José Dias's (servile) stiffness, which breaks down into his (equally servile) elasticity. My "formality", chosen no doubt partly because of the echo with "flexibility", is also an attempt to convey this stiffness. ScottBuccleuch, again, in his cavalier way, has decided to remove the word "natural" from its careful placement after this opposition, when it is applied to the change - in Chapter 5 he is, as we have said, "tão natural nesta como naquela maneira" - and apply it the first half only ("his natural gravity"), thus destroying the real complexity of José Dias’s character.

(d) Some of the other contrasts have to do with the nature of José Dias's character and his status in the family. Thus, the word "recados", translated - rightly - by Caldwell and me as "errands", is mistaken by Scott-Buccleuch as "business", which implies too active a role - the meaning is much closer to the English "message", as in colloquial English "to be sent on a message". Finally, in the last sentence, in translating "entrei a que Scott-Buccleuch, em um capítulo pontilhado de adjetivos difíceis, se obriga a mais dois traduzindo os verbos em "Mexia-se todo, falava de tudo" por "Restless and talkative" [desassossegado e falante]. O resultado é a necessidade de um outro adjetivo dispensável para "inquieto", "preoccupied”, que significa inquieto no sentido de preocupado, e não agitado, quase como irrequieto em português, que é certamente o sentido pretendido.

Na análise dos dois últimos adjetivos contrastantes, "teso" e "flexível", percebe-se que Caldwell não entendeu bem o primeiro e o traduziu por "tense" [tenso], primeiro significado proposto pelo dicionário Taylor, mas que nos remete ao campo semântico errado, ao da tensão psicológica, que não tem nenhuma relação com o caso; ela não percebeu que o vocábulo sugere a rigidez (servil) de José Dias, que cede à sua elasticidade (igualmente servil). O meu "formality" [formalidade], escolhido em parte pela sonoridade estabelecida com "flexibility", é também uma tentativa de transmitir esta rigidez; a forma da frase talvez tenha sido sugerido pela de Scott-Buccleuch. Este, mais uma vez, com o seu pouco caso, decidiu pela supressão da palavra "natural" da sua posição original, posterior ao contraste, quando é aplicado à mudança - no capítulo 5, ele é, como já citado, "tão natural nesta como naquela maneira” - destruindo, assim, a real complexidade do caráter de José Dias.

Outros contrastes dizem respeito ao caráter de José Dias e o seu status na família. Assim, “recados”, traduzida (corretamente) por mim e Caldwell como "errands", é mal interpretada por ScottBuccleuch que produz "business" [tarefas], o que implica uma atuação muito mais ativa - o significado é mais próximo de "message" em inglês, como "to be sent on a message" [dar um recado] do inglês coloquial. Por fim, na última frase, na tradução 
tratá-lo com palavras e gestos carinhosos”, Caldwell has brought in an "ingratiate" ("I tried to ingratiate myself by affectionate words and gestures"), and whether he is following her or not, Scott-Buccleuch reaches much the same solution - worsening it, in fact, by excluding "carinhoso" ("addressed him with ingratiating words and gestures"). This seems to me to be mistaken - and again, it is the status of the agregado, the relationship between Bentinho and José Dias, which is at issue. To me, "ingratiating" is too overt, makes it almost seem as if Bentinho is humiliating himself to the agregado - no doubt he is, but not on the surface. The whole point about the "carinho" is that it is part of the complex world of disguise and pretence which the relationship inhabits - so much so that Bento really does, by the end of the novel, feel a kind of “carinho” for José Dias: "Pobre José Dias! Por que hei de negar que chorei por ele?” The relationship between José Dias and Bento is one of real subtlety, the word "carinhoso" is carefully chosen, and Machado's - in a sense, Bentinho the narrator's - choices should be treated with respect, care and insight. The best example of its knife-edge nature is the moment is Chapter 19, short, but dedicated entirely to this matter - in the end, it all comes down to the tone, of command or supplication, in which the words "sem falta" (in "Preciso falar-lhe, sem falta, amanhã”) are pronounced.

(e) Finally, highlighted in red, is the phrase about the lottery ticket, which both Caldwell and Scott-Buccleuch translate as "a twentieth [share] of a lottery", and I decided (thinking that this would be more obscure to the reader, as it is to me) by replacing it with the essence of the matter, "cheap". I now think de "entrei a tratá-lo com palavras e gestos carinhosos”, Caldwell empregou "ingratiate" [bajular] ("I tried to ingratiate myself by affectionate words and gestures” [tentei bajulá-lo com palavras e gestos carinhosos]), não se sabe se Scott-Buccleuch a imita, mas propõe uma solução bastante semelhante e, na verdade, a piora, excluindo "carinhosos" ("addressed him with ingratiating words and gestures" [dirigi-me a ele com palavras e gestos bajuladores]). Esta opção me parece errada, e, mais uma vez, o que está em questão é a relação de agregado entre Bentinho e José Dias. Na minha opinião, "ingratiating” é manifesto demais e faz parecer com que Bentinho esteja se humilhando perante o agregado, o que indubitavelmente acontece, mas não de modo evidente. A questão em torno da palavra "carinho" é que ela é parte do complexo mundo de dissimulação e falsidade em que esta relação se estabelece, tanto que Bento, no fim do romance, sente mesmo um carinho por José Dias: "Pobre José Dias! Por que hei de negar que chorei por ele?” A relação entre José Dias e Bento é de uma sutileza intrínseca e o vocábulo "carinhoso" é cuidadosamente escolhido, logo as escolhas de Machado - de certa forma, as de Bentinho, o narrador - devem ser tratadas com respeito, cuidado e perspicácia. O melhor exemplo da extrema delicadeza destas relações encontra-se no capítulo 19, curto, mas totalmente dedicado a esta questão, em que, no fim das contas, tudo se resume ao tom de comando - ou de súplica - com o qual "sem falta" (em "Preciso falar-lhe, sem falta, amanhã") é pronunciado.

Finalmente, realçada em vermelho, a frase sobre o bilhete de loteria, que tanto Caldwell quanto Scott-Buccleuch traduzem por "a twentieth [share] of a lottery" [um vigésimo de loteria] e que eu, pensando que seria mais obscuro para o leitor, assim como é para mim, optei por substitui-lo pelo próprio conteúdo, “cheap” 
that was mistaken, and that they are right - simple fidelity to the original should dictate that, and the message is plain enough.

The main lessons to be learned from the analysis of this chapter, it seems to me, apart from the obvious ones of care and fidelity, are the need for the translator to be aware of at least two circles of meaning which go beyond the chapter in question, and without knowledge of which mistakes and resultant confusion are almost inevitable. The first concerns the character, social status, and position in the family of José Dias, the agregado. He is carefully introduced in chapters 4 and 5 of the novel, and as can be seen in the analysis above, the terms used in those chapters (for example "tão natural nesta como naquela maneira") set out the parameters in which his character is to be understood. This "circle" of meaning, the closest and most important, is confirmed by the search for some of the adjectives in other novels - but this is less important than the definitions laid out in the novel itself.

Moving to the second circle, some real understanding of what an agregado was, is necessary to the translator, and where it is absent, as in Scott-Buccleuch's "friend of the family", the result is real disaster. Such mistranslations of key words contribute to making the whole novel an unsolvable enigma to the reader, and are much more important than minor, subtle nuances of meaning, for their importance is structural. Both Caldwell and I translated "dependent”, which, while less colloquial than "agregado" - the differences between the words reflect the lesser importance of the phenomenon in Britain and America - still conveys the essence of the relationship. I should perhaps underline that this is simply a matter of cultural understanding. My emphasis on the subject, [barato]. Percebo agora que estava errado e eles certos - a fidelidade ao original devia ter me bastado e a mensagem é clara o bastante.

A principal lição a ser tirada a partir da análise deste capítulo, parece-me, além das óbvias do cuidado e fidelidade, é a necessidade de o tradutor estar ciente de pelo menos dois níveis de significado que ultrapassam o capítulo em questão e cujo desconhecimento provoca de forma quase inevitável erros e uma decorrente obscuridade. A primeira diz respeito à natureza, o status e a posição que José Dias, o agregado, ocupa na família. Ele é cuidadosamente apresentado nos capítulos 4 e 5 do romance e, como observado na análise acima, os vocábulos empregados nestes capítulos (por exemplo, "tão natural nesta como naquela maneira”) estabelecem as balizas segundo as quais o seu caráter deve ser entendido. Este "nível” de significado, a mais próxima e mais importante, é confirmada pela busca de alguns dos adjetivos em outros romances mas isto é, contudo, menos importante que as definições apresentadas no próprio romance.

No segundo nível, faz-se necessário que o tradutor compreenda de fato o significado de agregado e quando não o faz, como no caso de "friend of the family" de Scott-Buccleuch, o resultado é desastroso. Estes deslizes de tradução de palavraschave contribuem para tornar todo o romance um enigma insolúvel para o leitor e são muito mais relevantes que nuances sutis de significado, já que têm relevância estrutural. Caldwell e eu optamos por "dependent" [dependente], que apesar de menos coloquial que agregado - as diferenças entre as palavras refletem a importância menor do fenômeno nos Estados Unidos e na GrãBretanha - ainda transmite a essência da relação. Talvez eu devesse salientar que esta é meramente uma questão de 
while it obviously reflects the importance given by Roberto Schwarz to the topic of favour and clientelism - is also due my own analysis of José Dias's crucial importance in the novel, for in a real sense he is the trigger both of Bento's love for Capitu, and of his jealousy. If we fail to understand his motivations, which spring from his social position, a vital piece of the novel's jigsaw is removed.

\section{III}

In this final section, rather than comparing translations, I have decided to look at, and try to analyse, my own process of translating, on its own; to show something of the process when in direct contact with the text. To do this, I have chosen a short story, "Singular ocorrência”, which I am preparing for publication in an anthology. The main reasons for the choice are three: 1 ) it is one of my own favourite stories, and by common consent one of Machado's best; 2) I had already produced one version of it two months before writing this essay, and so was able to come back to it with some sense of distance - any translation requires this distance, Machado perhaps more than most; and 3) I have looked at the story from a critical point of view as well, especially in the introduction to my anthology of short stories in Portuguese - it thus gives some evidence of how the two ways of dealing with the story can interact. ${ }^{36}$ Obviously, one of the main difficulties is that of length - while it is imperative to deal with the text as a whole, certain issues will have to be chosen, to maintain a focus; however, within these restrictions, I have also tried to introduce some variety of focus. I should say, finally, that I am aware of the existence of conhecimento cultural. A minha ênfase à questão, ao mesmo tempo em que reflete a importância que Roberto Schwarz deu ao tema do favor e clientelismo, deve-se igualmente à minha própria análise da centralidade de José Dias no romance, pois de certa forma ele é o causador tanto do amor de Bento por Capitu quanto do seu ciúme. Se não entendemos as suas motivações, conseqüentes da sua posição social, uma peça fundamental do quebra-cabeça do romance é subtraída.

\section{III}

Nesta última seção, decidi, em vez de comparar traduções, considerar e tentar analisar o meu próprio processo de tradução, isoladamente, para mostrar algo do processo quando em contato direto com o texto. Para tal, escolhi a tradução de um conto, "Singular Ocorrência", que estou preparando para publicação em uma antologia. As principais razões para esta escolha são três: 1) É um dos meus contos favoritos e, por unanimidade, um dos melhores de Machado; 2) Já tinha produzido uma versão dele, dois meses antes de escrever este ensaio, o que me permitiu retomá-la com algum distanciamento - toda tradução exige este distanciamento, muito mais ainda talvez no caso de Machado; e 3) Já tinha uma visão crítica do conto da qual lancei mão em especial na introdução à minha antologia de contos em português, evidenciando, assim, como estes dois modos de lidar com o conto podem interagir. ${ }^{36}$ Uma das maiores dificuldades é certamente a extensão - apesar de ser imperativo lidar com o texto como um todo, determinados aspectos terão de ser privilegiados com vistas a delimitar a discussão; contudo, dentro destas limitações, tentei introduzir também abordagens e perspectivas 
another translation, in the anthology A Devil's Church and Other Stories, translated by Jack Schmitt and Lorie Ishimatsu (where it is called "A Strange Thing”), but I was not able to consult it before writing this essay - for my purposes here, this is an advantage, because it means that this study is of a different nature from those in the previous section.

First published in 1883, and then a year later in Histórias sem data, "Singular ocorrência" consists of a conversation between two men outside a church in the middle of Rio. They see a woman going in, and one of them tells the other her story. Her name, years back, was Marocas, and she was a prostitute. A married man, Andrade, fell in love with her, and they had an established relationship. One day, on St. John's Night, Andrade goes out of town with his wife for two days, and when he comes back, finds out, by a total accident - a leech who comes to beg money, and "by the way", tells him the story - that she has picked up a man in the street. Furious, he accuses her; she is completely distraught, disappears, and when he finally finds her, they are reconciled. Some months later, he buys her a house. The relationship continues until his death; after it, she considers herself his widow. The two men disagree as to the motivation for her "betrayal". One thinks it is the prostitute's fatal attraction to her trade, "la nostalgie de la boue", in a famous phrase from the French dramatist Émile Augier, the other more or less shrugs his shoulders and thinks it's a mystery.

Even this short summary of the story cannot avoid interpretation - in particular, the highlighting of the "simple" fact, only mentioned "in passing", that he buys her a house after the variadas. Devo acrescentar, por fim, que estou ciente da existência de outra tradução, na antologia The Devil's Church and Other Stories [A igreja do diabo e outros contos], traduzido por Jack Schmitt e Lorie Ishimatsu (em que recebeu o título de "A Strange Thing”[Uma coisa estranha]). Todavia, não tive acesso prévio a esse texto antes da escrita deste ensaio - para o que me proponho aqui, isto é uma vantagem, pois significa que este exame é de natureza diferente daqueles realizados nas seções anteriores.

Publicado pela primeira vez em 1883 e um ano mais tarde em Histórias sem data, "Singular ocorrência" consiste em uma conversa entre dois homens, do lado de fora de uma igreja, no centro do Rio. Eles vêem uma mulher entrando e um deles conta a história dela ao outro. Seu nome, anos atrás, era Marocas e ela era prostituta. Um homem casado, Andrade, se apaixonou por ela e os dois começaram uma relação amorosa. Certa vez, em uma noite de São João, Andrade viajou com a esposa por dois dias e quando voltou, descobriu, por acaso, que ela tinha se envolvido com um homem na rua. Furioso, ele a acusa; ela fica totalmente fora de si, desaparece e quando ele finalmente a encontra, eles fazem as pazes. Passados alguns meses, ele compra uma casa para ela. A relação continua até que ele morre, a partir de então, ela se considera sua viúva. Os dois homens discordam quanto à motivação da "traição" de Marocas. Um acredita que se deve à atração fatal que as prostitutas têm pelo seu ofício, "la nostalgie de la boue”, em uma famosa frase do dramaturgo francês Émile Augier; o outro, meio que dá de ombros e acha que é um mistério.

Nem mesmo este breve resumo do conto escapa a interpretações, em particular, o destaque do "simples" fato, mencionado incidentalmente, de que ele lhe dá uma casa depois da 
reconciliation. The reason for the betrayal (for the "singular occurrence", which is singular in both senses of the word), I argue, is that Marocas feels unprotected and lonely on that night, the more so as Andrade is with his family, and so in desperation searches for anything (even the "pobre-diabo" vulgar leech Leandro) to pass the time and give her warmth. In other words, this story, apparently about sex, is in fact about love, affection and security; in this case, the need for a woman who has given up everything for a man to have something of her own, some independence. Love cannot flourish in a situation of total dependence. It is a variant of the pervasive theme of "favour" - the reluctance of the middle-class male to turn dependence into greater equality.

How does this interpretation affect the process of translation? First, it should be said that I believe it brings the text itself to life in the reading - that is, the details of the story take on greater life and meaning once the story is understood in this way. Given that this is the case, the interpretation simply gives a greater urgency to be faithful to those details, to get the nuances right - in the end, this can only be shown by argument and example. We have already seen how important adjectives are in this process, in our analysis of the passage from Dom Casmurro: in this case, somewhat in the same manner, I intend to highlight different "areas" of meaning, and of implication in the story, and show how I have gone about translating them. In all this, I have to confess, the obvious facts that one has to be faithful to the original, and has to produce a fluent, subtle, readable English version, are almost one's only guides - that, and a faith that, in the end, the more faithful one is to meaning of the original, the better the translation will be, as a piece of English prose. Thus, although it may seem reconciliação. A razão para a traição (para a "singular ocorrência”, singular nas duas acepções da palavra), acredito, é que Marocas, sentindo-se desprotegida e só naquela noite, mais ainda pelo fato de Andrade estar com a família, em desespero, procura alguma coisa (até mesmo o pobre-diabo e sanguessuga do Leandro) para passar o tempo e lhe dar afeto. Em outras palavras, este conto, aparentemente sobre sexo, é na verdade sobre amor, afeição e proteção; neste caso, a necessidade de uma mulher, que abriu mão de tudo por um homem, possuir alguma coisa sua de fato, uma certa independência. $\mathrm{O}$ amor não pode prosperar em um contexto de total dependência. É uma variante do tema recorrente do "favor" - a resistência do homem de classe média em transformar a dependência em uma maior igualdade.

De que maneira esta interpretação afeta o processo de tradução? Antes de mais nada, é necessário dizer que acredito que ela confere vida ao próprio texto durante a leitura, ou seja, os detalhes do conto ganham em vida e significado se o conto for entendido dessa forma. Isto pressuposto, a interpretação nos impele a uma necessidade ainda maior de ser fiel àqueles detalhes, de entender os matizes - no fim das contas, isso só pode ser mostrado por meio de argumento e exemplo. Já vimos a centralidade dos adjetivos neste processo na análise do fragmento de Dom Casmurro. Aqui, pretendo destacar diferentes "áreas" de significado e de implicação no conto e evidenciar como lidei com elas no processo de tradução. Em tudo isso, devo confessar, os fatos óbvios que se tem de ser fiel ao original e produzir uma versão em inglês fluente, sutil, legível são quase as únicas balizas que se tem - isso e uma fé de que, no fim das contas, quanto maior a fidelidade ao significado do original, melhor e mais convincente será a tradução como uma narrativa legítima em inglês. Assim, 
that I have been concerned above all with accuracy and faithfulness to the original, the other side of the coin, the production of a good English version, is always present. I have tried to focus each issue on a single section, phrase, word, or group of words, and in each case on real difficulties of translation, which also illuminate the meanings of the original - often, in fact, the process of translation has brought these aspects of Machado's language and meaning to my attention.

The first "area" which can be noticed is a passage of text, the opening of the story, the conversation which precedes the beginning of the actual story (as far as "Diga"): it contains more than a quarter of the story's "paragraphs", each of which is in fact a speech, since the story is set in the form of a dialogue: one of the main aims of the translator should be to make this dialogue as natural as possible. Most importantly, this sets up the basic "situation" of the story, that of two men looking at and judging a woman. The way that they categorise women, eliminating options - "widow", "younger woman married to an older man and so ripe for extra-marital affairs", "spinster", and, on the other side "seamstress" etc., unwittingly show how superior they are, and how women, in their social and marital situations, their job options, are forced into categories. In Marocas' case, in fact, she is forced out of them into something unnameable and indistinct, a prostitute even though she doesn't look like one, a kept woman with no property of her own.

The most important thing, it seems to me, in this section, is to establish a conversational tone which is natural, colloquial, flows easily, and has something of the easy, worldly-wise tone of the two speakers. It seems to me, in fact, that this is so important to embora possa parecer que eu tenha me interessado sobretudo pela precisão e fidelidade ao original, o outro lado da moeda, a produção de uma boa versão em inglês, está sempre presente. Tentei concentrar cada aspecto em uma seção, frase, palavra ou grupo de palavras e, em cada caso, em dificuldades concretas de tradução, que iluminam também os significados do original - na verdade, o processo de tradução com freqüência chamou a minha atenção para estes aspectos do discurso de Machado e seu significado.

A primeira “área” que pode ser observada é um fragmento de texto: a abertura do conto, a conversa que antecede a história em si (até "Diga"), que encerra mais de um quarto dos "parágrafos" do conto, cada um dos quais é na verdade uma fala, uma vez que o conto se apresenta como um diálogo - um dos principais objetivos do tradutor deve ser tornar este diálogo o mais natural possível. Mais importante que isso, isto organiza a "situação" básica do conto, ou seja, a de dois homens olhando e julgando uma mulher. A forma como eles a categorizam, eliminando opções - "viúva", "mulher mais jovem casada com um homem mais velho e portanto madura para ligações extraconjugais", "solteirona” e, no sentido oposto, "costureira" etc., revelando inadvertidamente a própria superioridade e como as mulheres, em suas conjunturas sociais e conjugais, são forçadas à categorização. No caso de Marocas, ela na verdade foge a esse tipo de categorização e se encaixa em uma coisa indizível e indefinida, uma prostituta, ainda que não pareça, uma concubina sem posses.

O mais importante nesta seção, parece-me, é estabelecer um tom coloquial que seja natural, informal e fluente e que tenha algo do tom fácil e mundano dos dois personagens. Parece-me, na verdade, que isto é tão importante para o êxito do conto que 
the success of the story that a few slight "infidelities" might be allowed, so that this greater fidelity can be maintained. Here are a few instances: the first appears in the first sentence. To remain completely true to Machado's intentions, the title of the story, "Singular ocorrência", should be echoed here: "Há ocorrências bem singulares". However, "There are some singular occurrences", sounds far too formal in English - again, it is the problem of the dual level, Germanic/Latinate nature of English. Yet it seems wrong to change the title, the more so as "singular" is meant in two senses, "strange", and "one-off". My solution - not entirely satisfactory, I confess, is to keep "singular occurrence" for the title and for the final appearance, right near the end of the story, and change it here in the first sentence.

Once or twice, in this section, I have erred on the colloquial side: "Não ponha mais na carta", defined in the Houaiss dictionary as "não acrescentar mais nada ao que já foi dito", I have "reduced" this to "say no more", which carries the right tone of intra-male, slightly colluding familiarity about it. Above all, in the fourth paragraph, we have this speech: "Esse olhar está dizendo que a dama é uma sua recordação de outro tempo, e não há de ser de muito tempo, a julgar pelo corpo: é moça de truz”, which I translated: "By the look in your eyes, I can see she brings back memories, and recent ones, judging by her figure; she's a finelooking young woman.' These words produce rather different kinds of difficulty. The direct translation of "corpo" would be "body", but it seems to me that that kind of direct physical reference is too blunt to convey the situation in English (a "good body" is far too clinical - perhaps twentieth-century - in its implications), and that "figure" gets the meaning better, without algumas leves "infidelidades" devem ser admitidas de tal modo que esta fidelidade mais importante seja mantida. Alguns casos ilustrativos: o primeiro aparece na primeira frase. Com vistas a transmitir de todo a intenção de Machado, o título do conto, "Singular ocorrência", deveria ser retomada da seguinte maneira: "Há ocorrências bem singulares". Contudo, "There are some singular occurrences”, parece formal demais em inglês - é mais uma vez a questão da natureza dual do inglês, com palavras de origem germânicas e latinas. Entretanto, parece inapropriado mudar o título, ainda mais que "singular" se presta a dois sentidos, "raro" e "único". A minha opção, que confesso não ter sido totalmente satisfatória, foi manter "singular occurrence" no título e na última ocorrência, quase no fim do conto, e mudá-lo aqui na primeira frase.

Uma ou duas vezes nesta seção, "errei” do lado da coloquialidade: "Não ponha mais na carta", definido no Houaiss por "não acrescentar mais nada ao que já foi dito", "reduzi” a "say no more", que transmite o tom certo de informalidade levemente conspiratória entre homens.Há subjacente a isso uma superioridade masculina admitida, tão usual que chega quase a ser natural, apesar do sarcasmo inerente. Ela era "esbelta, mais linda do que hoje" e, acima de tudo, no quarto parágrafo, há o seguinte comentário: "Esse olhar está dizendo que a dama é uma sua recordação de outro tempo, e não há de ser de muito tempo, a julgar pelo corpo: é moça de truz", que eu traduzi por: "By the look in your eyes, I can see she brings back memories, and recent ones, judging by her figure; she's a fine-looking young woman.” [Pelo seu olhar, posso perceber que ela traz recordações, e recordações recentes, a julgar pelo porte; é uma jovem vistosa]. Essas palavras produzem tipos bastante diferentes de dificuldade. A tradução direta de "corpo" 
losing the sexual inference. "De truz" (a phrase unfamiliar to most Brazilians I have asked, and which must have fallen into relative disuse) means, according to the Houaiss dictionary, "de qualidade", and is used with that meaning in Dom Casmurro, chapter 100, in which José Dias refers to Escobar as "um marido de truz" (which I translated as "a first-class husband"). To say "she's good quality" would again be far too blunt - these things are insinuated rather than directly stated. My solution still doesn't satisfy me entirely - "moça" in particular is difficult, and "girl" will not do, its implications being far too young - yet some kind of youthfulness must be implied, because of the other man's surprise when he is told how old she really is.

Three other details illustrate the same point. The addition of “I suppose?" after “Old?” (for "É velho?) is intended slightly to emphasise the way the speakers categorise women and their marital situations, to assume that certain truths hold - "if she's married, she must have an old husband, who perhaps turns a blind eye to her adultery" - simply to underline, or even, perhaps, to interpret the tone which is already there in Portuguese. "She swept him off his feet”, while perhaps a somewhat liberal interpretation of "dominou-o", carries on the colloquial tone. Even "Go ahead" (as opposed, say, to "Go on"), for "Diga" is intended to have the same effect. seria "body", mas me parece que este tipo de referência física direta é objetiva demais para transmitir o contexto em inglês ("good body" é clínico demais, talvez muito século XX, em suas implicações) e "figure" passa melhor a idéia, sem perder a referência sexual. "De truz" (expressão incomum à maioria dos brasileiros a quem perguntei e que deve ter caído em relativo desuso) significa, de acordo com o dicionário Houaiss, “de qualidade” e é assim empregada em Dom Casmurro, no capítulo 100, quando José Dias refere-se a Escobar como "um marido de truz" (que eu traduzi como "a first-class husband" [um marido de primeira classe]). Dizer que "ela é de boa qualidade" seria mais uma vez direto demais - essas coisas são insinuadas e não declaradas abertamente. A minha solução ainda não me satisfaz plenamente - "moça” apresenta uma dificuldade específica e "girl” não funciona, pois implicaria muito pouca idade, ainda assim a escolha deve encerrar uma certa juventude, dada a surpresa do segundo homem quando lhe descobre a idade.

Três outros detalhes ilustram a mesma questão. O acréscimo de “I suppose?” seguido de “Old” (para “É velho?”) tem um pouco a intenção de reforçar o modo como os dois personagens categorizam as mulheres e seu estado civil, de supor que certas verdades se perpetuam -se for casada, deve ter um marido velho, que talvez feche os olhos para o seu adultério - simplesmente de destacar, ou até mesmo interpretar, o tom já presente em português. "She swept him off his feet" [Ela fascinou-o totalmente], embora talvez uma leitura liberal para "dominou-o", mantém o tom coloquial. Mesmo o "Go ahead" (em oposição a "go on”) para “Diga” tem a intenção de produzir o mesmo efeito. 
The second "area" refers to Andrade's character. He is in a sense the "third" man in the story, for he is seen through the eyes of the main narrator, who, as we have seen from the opening conversation, has his limitations. It so happens that three of the phrases most difficult to translate in the story have to do with him; I believe this is no accident, since he is the character in the middle, whose limits are tested, and who, in fact, changes, for when love and honour come into conflict, in the end honour loses. Most important is the fact that he is always seen through the eyes of others, and so every sentence looks both ways, so to speak. The three phrases in fact describe him before the crisis - this, too, is perhaps significant, for his character is then undefined - the crisis itself brings definition. He is, we should remember, a married man, with a wife who is "afetuosa, meiga, e resignada", words which seem to be, and perhaps are, somewhat cruel. But this is relatively unimportant in this story - the wife is kept in the background.

Like most men, Andrade has his sexual appetites and his emotions - only at the end of the story are both forced into action and choice, when he buys Marocas the house; before the "betrayal" and the flight, he either cannot or doesn't want to spend the money to give her security. In these three phrases, we see, first, that his appetites are perhaps stronger than most men's; second, that he feels some guilt about the fact that he is perhaps "exploiting" her; and finally, that he has what is commonly called "a dirty mind" - i.e. that perhaps independently of all this (or perhaps not), he likes a spicy story. In each case these truths are coloured by the narrator's language, and in each case the translator's difficulty is to get both these things over.
A segunda “área” refere-se a Andrade. Ele é de certa forma o terceiro homem do conto, já que é visto através do olhar do narrador, que, como vimos pelo diálogo introdutório, tem as suas limitações. Acontece que três das frases mais difíceis de traduzir do conto têm a ver com ele; não acredito que seja acidental, uma vez que ele é indefinido, seus limites são postos à prova e de fato sofre uma mudança, pois quando há um conflito entre amor e honra, é esta que sai perdendo. As três frases descrevem-no antes da crise - isto também é significativo, pois o seu caráter permanecia indefinido - a crise em si traz a definição. Ele é, lembremo-nos, casado com uma mulher "afetuosa, meiga, e resignada”, palavras que parecem ser, e talvez sejam, um tanto cruéis. Mas isto tem uma importância relativa no conto - a esposa é mantida em segundo plano.

Como a maioria dos homens, Andrade tem seus desejos sexuais e emoções, somente no fim do conto ambos são forçados à ação e à escolha, quando compra a casa para Marocas; antes da "traição" e da briga, ele não pode ou não quer gastar dinheiro com a sua segurança. Nestas três frases, percebemos, em primeiro lugar, que os seus desejos talvez sejam mais fortes que o da maioria dos homens; em segundo, que ele sente uma certa culpa com o fato de estar "tirando proveito" dela e, por fim, que ele tem o que normalmente se chama de "mente suja", ou seja, que talvez independente de tudo isso (ou talvez não) ele goste de histórias picantes. Em cada caso, estas verdades são matizadas pelo discurso do narrador e, em cada um deles, a dificuldade do tradutor é transmitir ambas idéias. 
The first phrase, "esperou, já alvoroçado, porque ele tinha em alto grau a paixão das mulheres", is right at the beginning of the description of him, as he sees Marocas approaching through the square. I translated: "and waited, his interest already aroused, for he had a great passion for the ladies". Here, the implication is that Andrade is what in English would be called “a ladies' man”, but for the narrator to use that phrase itself would imply criticism or distance on his part, and that, I believe, is just what Machado wants to avoid - there is something of collusion in these words, in the disguising of pure sexual appetite; I tried to convey some of this by the use of the word "aroused", which has a sexual colouring. The use of "ladies" rather than "women" for "mulheres", however, is intended to convey just this collusion; "the ladies" is intended to increase that same effect. "Mulheres" would normally be "women"("dama", is the normal word for "lady", as in fact I have translated it in its four appearances in the story), but here cannot be - there is even the danger, if "women" is used in English, of implying that he is attracted to women, as opposed to men, a total irrelevance and distortion of the meaning.

The second phrase appears when the narrator tells him that she has pawned some jewels to pay a seamstress's bill (i.e. what little money she has, she uses to look good to him). "Esta notícia abalou-o muito; não juro, mas creio que ficou com os olhos molhados”. I translated: “This upset him a great deal; I can’t swear, but I think there were tears in his eyes". Here, most obviously, the narrator intervenes, to say he "can't swear” but he "thinks" ("não juro, mas creio") that his eyes are wet, and so to leave us in some doubt about how upset Andrade really is - is this sentimental pity for her, or real humiliation and concern for her
A primeira frase, "esperou, já alvoroçado, porque ele tinha em alto grau a paixão das mulheres”, está no começo da sua descrição, quando ele vê Marocas atravessando a praça, em sua direção. Traduzi: "and waited, his interest already aroused, for he had a great passion for the ladies” [e esperou, seu interesse já alvoroçado, pois tinha uma grande paixão pelas damas]. Neste ponto, a questão é que Andrade é o que se chama em inglês de "a ladies' man” [grande admirador das mulheres, quase paquerador], mas o emprego desta frase pelo narrador implicaria crítica ou distanciamento e isto, acredito, é justamente o que Machado quer evitar - há algo de conluio nestas palavras, na dissimulação do mero desejo sexual. O emprego de "ladies" ao invés de "women" para "mulheres", todavia, tem a intenção de transmitir justamente este conluio; o artigo em "the ladies" se propõe a destacar este mesmo efeito. "Mulheres" normalmente seria traduzido por "women" ("dama” é a palavra equivalente para "lady", como de fato a traduzi nas suas quatro ocorrências no conto), mas não nesse caso - há mesmo o perigo, se "women” for empregado, de sugerir que ele sente atração por mulheres, $e$ não por homens, o que seria uma absoluta irrelevância e uma distorção do sentido.

A segunda frase aparece quando o narrador conta que ela penhorou algumas jóias para pagar a costureira (ou seja, o pouco dinheiro que ela tinha, ela usava para ficar bonita para ele), "Esta notícia abalou-o muito; não juro, mas creio que ficou com os olhos molhados”. Traduzi: “This upset him a great deal; I can't swear, but I think there were tears in his eyes" [Isto o perturbou muito; não posso jurar, mas acho que havia lágrimas em seus olhos]. Neste ponto, obviamente, o narrador intervém quando diz que não jura, mas crê que seus olhos estavam molhados, deixando-nos incertos quanto ao real nível de perturbação de Andrade - é 
which would push him in the direction of giving her stability? Nothing in the story lets us know, in fact, for events take over. One is reminded of the diary entry for 24 August 1888 in Memorial de Aires, in which Aires (who, like his author, is myopic!) spends three paragraphs discussing whether he saw a tear on Fidélia's eyelash two days before, concluding that "Tudo é assim vago e contraditório também." The difficulty for the translator is focussed not so much on the doubt itself, easy enough to translate ("I can't swear, but I think...") but on the "accidental" fact that "wet" for "molhados" will not do - something about the fact that "molhados" is a past participle, implying, however distantly, that "something" has caused the wetness, is removed in the English, leaving a balder impression that in the original. When I say "accidental", I mean that it is purely the differences between the two languages which cause the difficulty - Spanish and French, with "mojados" and "mouillés" pose no such problems. None of the synonyms ("damp”, "moist”) will do either, and one is pushed in the direction of "tears", a word which Machado has probably avoided, because he wants to remain in the area of doubt, and "lágrima" is too strong; still, in English, it is the best one can do.

The third phrase occurs just before the fateful revelation of her night with Leandro, and so at the end of the period of "indecision": "o Andrade, que dava o cavaco por anedotas eróticas, perguntou-lhe se eram amores". I translated: "and Andrade, who had an appetite for spicy stories, asked him if it was some love affair". Here, three phrases/ words "dava o cavaco", "anedotas eróticas", and "amores" present difficulties - we are back at Andrade, the ladies' man, and in fact somewhat worse than the one who had "em alto grau a paixão das mulheres", the more compaixão meramente sentimental por ela ou legítima humilhação e preocupação que o levaria a lhe dar estabilidade? Nada no conto indica a resposta, pois, na verdade, os incidentes têm prioridade. Isto traz à mente o registro do diário referente ao dia 24 de agosto de 1888, no Memorial de Aires, em que Aires (que, a exemplo do autor, é míope) discute em três parágrafos se viu uma lágrima no cílio de Fidélia dois dias antes, concluindo que "Tudo é assim vago e contraditório também”. A dificuldade da tradução não está tanto na hesitação em si, fácil de traduzir ("I can’t swear, but I think...”), mas no fato "acidental” de que "wet” não funciona como "molhados" - o fato de que "molhados" é um particípio, o que implica, ainda que indiretamente, que "algo" causou a umidade, é subtraído da versão em inglês, causando uma impressão mais direta que a do original. Quando digo "acidental”, refiro-me simplesmente às dificuldades causadas pelas diferenças entre as duas línguas - o espanhol e o francês com "mojados" e "mouillés" não apresentam esse tipo de problema. Nenhum dos sinônimos ("damp", "moist”) funcionaria, e somos forçados a usar "tears" [lágrimas], palavra que Machado provavelmente evitou por querer permanecer na área da incerteza; ainda assim, em inglês, é o melhor que se pode fazer.

A terceira frase aparece pouco antes da revelação decisiva da noite com Leandro e, passado o período de "indecisão”, há: “o Andrade, que dava o cavaco por anedotas eróticas, perguntou-lhe se eram amores". Traduzi: "and Andrade, who had an appetite for spicy stories, asked him if it was some love affair” [e Andrade, que tinha predileção por histórias picantes, perguntou-lhe se era um caso amoroso]. Aqui, três questões, a saber, "dava o cavaco", "anedotas eróticas" e "amores”, apresentam dificuldade retornamos a Andrade, o admirador das mulheres, e, na verdade, 
so if we contrast him with Marocas, who, in spite of her profession, has "modos sérios" and "linguagem limpa". The translation of the first phrase was suggested by the example of its use in the Houaiss dictionary: "ele dava o cavaco por umas boas sardinhas"; the idea of "appetite”, not far from sexual implications, too, seems especially appropriate. "Anedotas eróticas" is a typical case in which it is difficult to judge the level of familiarity of the original - "erotic anecdotes" in English would be completely wrong, but the difference in level has much to do, again, with the "dual-level" nature of English, the difference between words of Latinate and Germanic origins, which means that what sounds normal in Portuguese can sound formal in English, a danger reinforced by the context here, which is anything but formal. "Spicy stories", however, seems much better than "dirty stories", for it retains something of the distance and sympathy of the narrator for Andrade, which we have noticed in the earlier phrase "tinha em alto grau...” Finally, "amores": obviously, in the plural, this means something quite different from "amor", a word which in fact doesn't appear in the story - only the verb "amar" appears (twice), referring to the real thing. It remains difficult to translate: none of the alternatives given in the excellent Concise Oxford Thesaurus is ideal: for "An affair with a married man (sic) it gives: love affair, relationship, romance, liaison, affair of the heart, intrigue, amour, affaire. The first was chosen because it involves the word love, but qualifies it, as is true in the plural form of the original. um tanto pior que aquele que tinha "em alto grau a paixão das mulheres”, tanto mais se o compararmos a Marocas, que, apesar da profissão, tem "modos sérios" e "linguagem limpa". A tradução da primeira decorre de um exemplo do dicionário Houaiss: "ele dava o cavaco por umas boas sardinhas"; a idéia sugerida por "appetite", com possíveis conotações sexuais, parece também bastante apropriada. "Anedotas eróticas” é um típico caso em que o grau de formalidade do registro do original é difícil de julgar "erotic anecdotes" estaria totalmente errado, mas a diferença de registro está muito ligada, novamente, à natureza dual do inglês e a diferença entre as palavras de origem latina e as de origem germânica, o que significa que o que soa corrente em português pode soar formal em inglês, risco reforçado pelo contexto, que não tem nada de formal. "Spicy stories” [histórias picantes], contudo, soa melhor que "dirty stories” [histórias sujas] por preservar um pouco do distanciamento e da empatia do narrador por Andrade, o que observamos na frase anterior ("tinha em alto grau..."). Finalmente, "amores", que, assim, no plural, difere de "amor", vocábulo que não aparece no conto - apenas o verbo "amar" aparece (duas vezes), referindo-se ao amor físico. A tradução é difícil - nenhuma das alternativas apresentadas pelo excelente Concise Oxford Thesaurus é ideal, para "An affair with a married man" [um caso com um homem casado] (sic) ele lista: love affair e affair of the heart [caso amoroso], relationship [relação], romance, liaison [concubinato], intrigue [amor clandestino], amour, affaire [caso]. A primeira opção foi escolhida porque inclui a palavra amor, sem qualificar a relação, bem como na sua forma plural no original. 
Finally, I want to consider the matter of "cultural translation", by which I mean references to things which belong to the culture of the original, but which the foreign reader may or may not know: place-names, references to literary works, and cultural differences of other kinds, which may lead either to mystification (who on earth was he? why mention that?), or, more insidiously, may make the reader think he understands, when in fact something else is meant. We have seen how important such things are in the case of the agregado, for instance, or the "bênção" in the passage from Memórias póstumas. In part, too, it is the same problem mentioned in the first section, in my discussion of the world Machado describes, which is in apparent conformity to European models, but subtly, "secretly", different. How much (if at all) should we annotate? Are there other ways of conveying information? "Singular ocorrência", which has a wide range of such references for such a short story, provides an excellent means of considering the problem, and trying to establish a rough guide to how to deal with it - though, as we will see, there will always be grey areas.

It should be emphasised first of all that this is not a matter over which the translator has complete control - that is, if he has a contract with a publisher - for the publisher will (or should) have their own ideas about what is to be done in this case. It also varies from case to case - for example, when editing "Singular ocorrência" for the anthology published by the Companhia das Letras, I put in a total of five footnotes, the longest six lines long, one to explain the references to Paula Brito's shop, the Rossio and the equestrian statue of Dom Pedro I, three of them to explain the cultural references to the three plays mentioned in the story, and a
Quero, por fim, considerar a questão da "tradução cultural”, que é como me refiro às questões relativas à cultura de partida e que podem ser ou não do conhecimento do leitor da tradução: nomes de lugares, referências a obras literárias e diferenças culturais de outras naturezas, que podem ser intrigantes (Quem é esse aí? Por que mencionar isso?), ou, de uma maneira mais insidiosa, levar o leitor a imaginar que entendeu a referência quando, na verdade, a intenção do texto era diferente. Vimos a relevância de tais aspectos no caso do agregado, por exemplo, ou da bênção no trecho do Memórias póstumas. Isto é, em parte, também, a mesma questão abordada na primeira seção, quando discuti o mundo que Machado descreve, que é de aparente conformidade com os modelos europeus, mas que deles diverge sutil e "discretamente". Devemos lançar mão de notas explicativas e se sim, até que ponto? Há outras maneiras de transmitir informações? "Singular ocorrência", que oferece uma grande variedade de tais referências para um conto tão breve, apresenta-se como um rico material para examinar a questão e para tentar estabelecer algumas linhas gerais acerca de como lidar com ela embora, como veremos a seguir, sempre haverá áreas movediças.

Antes de mais nada, deve ser ressaltado que esta não é uma questão sobre a qual o tradutor tem controle total - isto é, se tem um contrato com uma editora - pois a editora tem (ou deveria ter) idéias próprias de como agir em um caso assim. Há também variações de caso para caso; por exemplo, quando estava editando "Singular ocorrência” para a antologia publicada pela Companhia das Letras, acrescentei um total de cinco notas, das quais a mais extensa tinha seis linhas: uma para explicar as referências à loja Paula Brito, ao Rocio e à estátua eqüestre de Dom Pedro I, três para explicar as referências culturais às três peças mencionadas no 
short one to explain that the "Praia Grande" is the present Niterói. This seemed wise in any case, but it should be said that I was highly influenced by an excellent article, mentioned in the introduction to the anthology, by João Roberto Faria, "Singular ocorrência teatral", in which he argues for the importance of the three French plays, "La Dame aux Camélias", "Le mariage d'Olympe", and "Je dîne chez ma mère", respectively by Alexandre Dumas Fils, Émile Augier, and Lambert Thiboust and Adrien Decourcelle. ${ }^{37}$ The information given us by Faria helps a great deal towards understanding the central problem of the story, Marocas' motivation, and it seemed genuinely helpful, if perhaps not completely essential, to provide it.

Still, the general principle should surely be to avoid footnotes, which interrupt the reading and risk imposing the editor or translator's point of view - there is nothing more irritating than consulting an endnote in an annotated edition, and finding that in their anxiety to inform, the editors, for instance, tell us the end of the plot! As I say, there are no absolutes in this matter. Sometimes, information can be perfectly well conveyed by adjustment of the text. A simple case of this is the substitution of "Niterói" for "Praia Grande" - both names were used in the nineteenth century in any case, and any reader familiar with Rio de Janeiro will be familiar with the other city. Another, equally simple, but contrasting example where a note cannot be avoided can be found in "A causa secreta", where a man is knifed by a member of a capoeira gang. ${ }^{38}$ To leave the word unexplained would be absurd, and even modern readers familiar with it may well have the wrong idea, thinking of it in its modern context, where it has become more like a form of dance or a "martial art" than a threat to the peace. Between these conto e uma curta para informar que "Praia Grande” é a Niterói atual. Isto parece acertado em todo caso, mas devo dizer que fui muito influenciado por um artigo excelente, mencionado na introdução à antologia, de João Roberto Faria, "Singular ocorrência teatral”, em que ele discute a importância das três peças francesas, "La Dame aux Camélias" [A dama das Camélias], "Le mariage d'Olympe" [O casamento de Olímpia], e "Je dîne chez ma mère” [Janto com minha mãe], de Alexandre Dumas Fils, Émile Augier, e Lambert Thiboust e Adrien Decourcelle ${ }^{37}$, respectivamente. A informação apresentada por Faria favoreceu a compreensão do problema central do conto, a motivação de Marocas, e pareceu genuinamente proveitosa, se não absolutamente essencial, para esclarecê-la.

Contudo, a norma corrente seria certamente evitar as notas de rodapé, que interrompem a leitura e arriscam impor o ponto de vista do tradutor ou do editor - não há nada mais irritante que consultar uma nota explicativa em uma edição anotada e descobrir que no anseio de informar, os editores, por exemplo, revelam o fim da história! Como disse, não há imperativos para essa questão. Em alguns casos, a informação pode ser perfeitamente ajustada no corpo do texto. Por exemplo, a substituição de "Praia Grande" por Niterói - ambos nomes eram usados no século XIX, e o leitor que tem conhecimento do Rio de Janeiro, tem também da outra cidade. Exemplo contrastante, e igualmente simples, em que a nota é imprescindível está em "A causa secreta", em que um homem é esfaqueado por um membro de uma malta de capoeiras. ${ }^{38}$ Seria absurdo deixar esta palavra sem explicação e mesmo os leitores atuais, que a conhecem, poderiam ficar com a idéia errada, considerando-a no seu contexto atual em que está mais ligada a um tipo de dança ou a uma "luta marcial" 
two extremes, as we will see, lie examples which are not quite so clear-cut. Obviously, too, the translator's problem is not the same as the editor's - in general, it is worse, because the reader's awareness of the context is much less.

We can begin with the simplest: the names of places, streets and buildings. Igreja da Cruz, Rua do Sacramento, Alagoas, Bahia, Rossio, Gávea, Jardim Botânico, Catumbi - all these are not so much unimportant as they are self-explanatory. The most important contexts are those of class and to some extent of distance from the centre of Rio (Gávea, Jardim Botânico, Catumbi), and they are all more or less clear in their own context. A slight difficulty is provided by the references to Paula Brito and the statue of Dom Pedro, but since any explanation would be relatively long and would contain information not really relevant to the story, they can be safely, if somewhat sadly, left alone - to a Brazilian readership, more familiar with the place, and the historical facts involved (e.g. with the figure of Dom Pedro I), a note is useful.

When we come on to the cultural references, things become progressively more difficult. The Lady of the Camellias was explained in Contos: uma antologia, but even there the explanation concentrated more on the play's reception in nineteenth century Brazil, and the controversy it aroused, than on the play itself, which is famous enough to obviate a note. When we come to Augier, I had thought that I could translate the phrase from Le Mariage d'Olympe "a nostalgia da lama” back into French "nostalgie de la boue", since it has become famous enough to be included in the Concise Oxford Dictionary of Quotations, but others have objected that the words are opaque to most people, and que a uma ameaça à ordem pública. Entre estes dois extremos, como veremos, há exemplos cujos contornos não são muito definidos. Claramente, o problema do tradutor não é igual ao do editor; é, em geral, pior, pois a noção de contexto do leitor é bastante mais limitada.

Podemos começar com o mais simples: nomes de lugares, ruas e prédios. Igreja da Cruz, Rua do Sacramento, Alagoas, Bahia, Rocio, Gávea, Jardim Botânico, Catumbi, que embora tenham importância, dispensam explicação. Os contextos mais importantes são os de classe e, até certo ponto, os de distância em relação ao centro do Rio (Gávea, Jardim Botânico, Catumbi), e eles se apresentam com alguma clareza no próprio contexto. Uma certa dificuldade surge com as referência à loja Paula Brito e a estátua de Dom Pedro, mas já que qualquer tentativa de explicação seria relativamente extensa e compreenderia informações não tão relevantes ao conto, elas podem ser com alguma segurança e certa tristeza deixadas de lado - para o público brasileiro, mais familiarizado com o lugar e com os fatos históricos envolvidos (por exemplo, a figura de Dom Pedro I), a nota é útil.

Quando lidamos com referências culturais, as coisas passam progressivamente a ficar mais complexas. A dama das Camélias foi explicada no Contos: uma antologia, mas mesmo ali a explicação se concentrava mais na recepção da peça no século XIX, no Brasil, e na controvérsia que gerou que na peça em si, famosa o suficiente para prescindir de nota. No caso de Augier, pensei que podia traduzir a frase "la nostalgie de la boue", da $L e$ Mariage d'Olympe por “a nostalgia da lama”, já que tinha ficado famosa o suficiente para ser incluída no Concise Oxford Dictionary of Quotations, mas alguns alegaram que a frase era obscura para a maioria das pessoas e, assim, "nostalgia for the 
so "nostalgia for the gutter" has been substituted. Again, although we miss the dialogue between the two plays, enough information is present to make a note superfluous.

The most delicate case of the three is the final one, the one-act play Je dîne chez ma mère. Not only is it much the least familiar of the three, so that no one could be expected to know about it - it is also the one most important to the plot of the story. In the Anthology, I gave a brief description of the play, which underlines the point about the loneliness of the prostitute, left with no family at festival time. Even here, though, I think, a note can be avoided - indeed, in the original, Machado has gone to some pains to provide the basic information about the situation in the play, so that, although Sophie Arnoult may be as much a mystery as the equestrian statue or Paula Brito, the main point is made, and we can be content with that.

Our troubles are not over, however. In consonance with what has been said about the secrecy of Machado's secrecy, two small passing references to customs and social relations of the time, which a reader contemporary with Machado would pass by without a second thought, but which are alien to us, make one wonder if a note might not be necessary, or at least helpful. The first of these is “a festa de São João”, important because it leaves Marocas alone at a traditional family festival - if it had been Christmas, all would have been clear, and there is a temptation to say (in a note) that, in the nineteenth century, it had that importance. Even so, it seems excessive to put a note in - often, in these cases, as in the example of the adjective "casmurro" we saw earlier, the choice is not so much between doing nothing and do something, but between doing nothing and risking doing too much. gutter” [literalmente, a nostalgia da sarjeta] foi substituída. Mais uma vez, embora o diálogo entre as duas peças fique faltando, há informação suficiente para dispensar o emprego de notas.

O caso mais delicado dos três é o último, a peça de um único ato, Je dîne chez ma mère. Não apenas por ser a menos conhecida das três e tanto que não se tem a expectativa de que ninguém conheça, como também é a mais importante para o enredo do conto. Na antologia, fiz uma breve descrição da peça, que destaca a questão da solidão da prostituta, destituída de família nos feriados. ${ }^{39}$ Contudo, acredito que mesmo aí pode-se evitar o uso de notas - na verdade, no original, Machado esforçou-se para apresentar as informações básicas e circunstanciais da peça, tanto que, embora Sophie Arnoult seja possivelmente tão obscura quanto a estátua eqüestre de Dom Pedro ou a loja Paula Brito, o seu propósito é cumprido e podemos nos contentar com isso.

Contudo, nossos problemas não acabam. Em consonância com o que foi dito sobre a reticência de Machado, duas breves e ligeiras referências a costumes e relações sociais de então, que um leitor contemporâneo de Machado leria sem pensar duas vezes, mas que nos são estranhas, poderiam fazer com que se pensasse que uma nota fosse necessária, ou pelo menos útil. A primeira é a “Festa de São João", importante por ser a causa de Marocas ficar sozinha em uma festa familiar tradicional - se fosse Natal, tudo estaria resolvido e há a tentação de dizer (em uma nota) que no século XIX tinha uma importância equivalente. Mesmo assim, parece excessivo acrescentar uma nota - freqüentemente, em tais casos, como no exemplo do adjetivo "casmurro" comentado anteriormente, a escolha não é tanto entre não fazer nada ou fazer alguma coisa, mas entre não fazer nada e arriscar fazer demais. 
The final example is the "criada de Marocas, uma preta forra, muito amiga da ama", translated as "Marocas's maid, a freed black, very close to her mistress" a description which, almost certainly, is intended to cast a good light on Marocas's character. Whether she has freed her or not (the word “forra” doesn't tell us), the fact that she is "muito amiga da ama" makes it plain that Marocas is kind to those (even) lower down the social scale than herself, always a good sign in Machado (as elsewhere, of course) Prudêncio provides an example of the opposite. Here again, however, our understanding of what slavery "must have been like" must guide us - the use of the word "close", rather than "friendly" of "a good friend of her mistress", is intended to convey a degree of real intimacy. It should be noted, too, that she is later, in the same paragraph, referred to as "a preta" (literally, "the black woman”); here, to refer to her by her colour would have different connotations in English, as if her colour was being called attention to, which is not true in Brazilian Portuguese. The best equivalent is simply to leave her as "she", nor is this inaccurate translation, since the meaning of the original is better conveyed.

\section{IV}

In the epigraph to this essay, Paul Ricoeur says that translators should above all possess and wide and deep knowledge of a culture, based on a great deal of reading, and that everything else, individual words, sentences, etc., depends on that knowledge. Is this so? Some theorists, like Antoine Berman, say that translators should translate from various languages, and he himself has translated from German and Spanish into French - this would
O outro caso é "uma criada de Marocas, uma preta forra, muito amiga da ama”, (traduzido por "Marocas's maid, a freed black, very close to her mistress"), descrição que certamente pretende enaltecer o caráter de Marocas. Ignora-se se ela a libertou (a palavra forra não nos informa), o fato de ela ser "muito amiga da ama" deixa claro que Marocas é simpática àqueles que estão mais abaixo (ainda) que ela na escala social, sempre um bom sinal em Machado (bem como em outros, certamente) - Prudêncio é um exemplo do contrário. Contudo, neste ponto, mais uma vez, o nosso entendimento "de como deveria ser" a escravidão deve nos guiar - o emprego de "close" [íntima] ao invés de "friendly" [amigável] ou "a good friend of her mistress" [boa amiga da sua ama] tem a intenção de transmitir um nível de intimidade legítima. Deve ser observado igualmente que mais adiante, no mesmo parágrafo, ela é chamada "a preta”; aqui, referir-se a ela pela cor teria uma conotação diferente em inglês, como se sua cor fosse realçada, o que não se aplica em português do Brasil. O melhor equivalente é usar "she” [ela], o que não incorre em deslize de tradução, uma vez que o significado do original é melhor transmitido.

\section{IV}

Na epígrafe que antecede este ensaio, Paul Ricoeur diz que os tradutores deveriam antes de mais nada possuir um conhecimento vasto e profundo da cultura, fundamentado em muita leitura, e que todo o resto, palavras isoladas, frases, etc., resulta deste conhecimento. É, de fato, assim? Alguns teóricos, como Antoine Berman, dizem que os tradutores devem traduzir de várias línguas e ele mesmo traduziu do alemão e do espanhol para 
seem to imply that linguistic ability, along with a non-ethnocentric attitude to translation, are more important than intimate knowledge of a culture. Speaking for myself, I find that I am only really happy translating, not only from Portuguese, but from Brazilian Portuguese. The reasons are no doubt largely cultural - that is, I have studied and read about Brazil a great deal, and visited it many times. They are also, however, partly linguistic; in a novel by, say, Machado de Assis, or Milton Hatoum, I can be reasonably confident that I can "hear" the language, and that gives me the sense that I can understand at a deeper level - feeling the rhythm and the tone of the original makes it (or so it seems to me) easier to "hear" an English equivalent, or near-equivalent. Indeed, the dominant impression I have of Helen Caldwell's translations (less so in William Grossman's case), is that, in the end, they lack that dimension. ${ }^{40}$

As I said at the beginning of the essay, I have no larger theoretical insights into translation - I have decided, in Berman's words, to "reflect" on my "experience", and we have seen some evidence that different authors may suit different translators. However, I am struck by how often, in every passage I have analysed, the linguistic and the cultural cannot be prised apart, and the translator has to keep his eye on both. Perhaps this is most perfectly displayed in the analysis of the adjectives in the passage from Dom Casmurro. To come as close to Machado's meaning as possible, it is useful to know not only what the words mean in the dictionary, but to know how they are employed at other moments in Machado's work; most importantly, however, we have to see how, in what terms, José Dias is portrayed at other moments in the novel, and, beyond that, what an agregado is, something which o francês; isto poderia implicar que a habilidade lingüística e uma atitude não etnocêntrica relativa à tradução são mais importantes que o conhecimento profundo da cultura. Quanto a mim, só me sinto contente traduzindo quando o faço não só do português, mas do português do Brasil. Os motivos são sem dúvida em grande medida culturais - ou seja, estudei e li muito sobre o Brasil e o visitei várias vezes. Contudo, são igualmente em parte lingüísticos; em um romance, por exemplo, de Machado de Assis ou de Milton Hatoum, sinto-me razoavelmente confiante de que posso "escutar" a língua, o que me dá a impressão de que posso atingir um nível mais profundo: sentir o ritmo e o tom do original facilita (ou assim me parece) "escutar" um equivalente em inglês ou um equivalente próximo. Com efeito, a impressão predominante que tenho com as traduções de Helen Caldwell (menos no caso das de William Grossman) é de que, no fim das contas, elas carecem dessa dimensão. ${ }^{40}$

Como disse no começo do ensaio, não sigo nenhuma teoria de tradução específica, decidi, de acordo com Berman, "refletir" sobre a minha "experiência”, e percebemos que diferentes autores podem se adequar a diferentes tradutores. Todavia, surpreendo-me com a freqüência, em cada passagem que analisei, de que aspectos lingüísticos e culturais não podem ser negligenciados e de que o tradutor deve se manter atento simultaneamente a ambos. Talvez isso seja mais claramente demonstrado na análise dos adjetivos no trecho de Dom Casmurro. Para aproximar-se o máximo possível da intenção de Machado, faz-se necessário saber não somente o significado das palavras no dicionário, mas também como elas estão empregadas em outros momentos na obra de Machado; contudo, o mais importante é analisar como, em que termos, José Dias é apresentado em outras 
cannot be separated from (for instance) slavery, and the way Brazilian society was, (and is) constituted.

Can we be reasonably certain that Machado's reputation beyond Brazil, at least in English, holds a brighter future? I am quite unsure, I have to confess, and when faced with such unexpected obstacles as Gregory Rabassa's translations, frustration and despair are the order of the day. I have recently discovered that Machado himself very much wanted to be read outside Brazil (in Portugal as well as in other languages) and was rightly aware of the importance of his own work. ${ }^{41}$ Frustration began in his own lifetime; and it may even be that his clipped, economical, almost elliptical style doesn't help - "Opacam-se vidros", after all. But these problems are not insuperable. It will, as I have suggested, probably be a long process - who knows, however, if one of those strange moments of cultural empathy which resulted in the translations of the 1950s may happen? The anthology of short stories I am now in the process of translating will be carefully organised so that the stories illuminate each other, reducing any possible sense of mystification. We have to live in hope, and meanwhile translate him with all the competence and empathy at our command. passagens ao longo do romance e, além disso, compreender o significado e a posição do agregado, algo que não pode ser apartado (por exemplo) da escravidão e de como a sociedade brasileira era (e é) constituída.

Podemos ter alguma segurança de que a reputação de Machado fora do Brasil, pelo menos em inglês, tem um futuro mais promissor? Não tenho tanta certeza, devo confessar, e quando me deparo com obstáculos tão imprevistos como as traduções de Rabassa, a frustração e o desespero estão na ordem do dia. Descobri recentemente que o próprio Machado queria muito ser lido fora do Brasil (tanto em Portugal, como em outras línguas) e que estava (acertadamente) ciente da relevância da própria obra. ${ }^{41}$ A frustração começou em vida e pode até ser que o seu estilo conciso, econômico, quase elíptico não ajude - cabe lembrar de “Opacam-se vidros”. Mas estas dificuldades não são insuperáveis. Será, como sugeri, um longo processo. Quem sabe, contudo, se uma daquelas conjunturas singulares de empatia cultural que resultou nas traduções na década de cinqüenta acontecesse? A antologia de contos que estou no momento traduzindo terá uma organização cuidadosa de tal modo que os contos interajam, reduzindo qualquer possível dubiedade. Precisamos manter a esperança e enquanto isso traduzi-lo com toda a competência e empatia que pudermos. 


\section{Notes}

1 Paris: Bayard, 2004 (p. 56); I thank my translator, Luana Freitas, for recommending me this book.

${ }^{2}$ My only previous experience of writing on translation was an essay on three English-language anthologies of the poetry of Carlos Drummond de Andrade, published in 1986, and republished as an appendix to my book Influências $e$ impasses: Drummond e alguns contemporâneos (São Paulo: Companhia das Letras, 2003), pp. 281-99.

${ }^{3}$ La Traduction de la Lettre ou L'Auberge du lointain (Paris: Seuil, 1999), pp. $15-16$

${ }^{4}$ In Machado de Assis: Reflections on a Brazilian Master (Austin, Texas: University of Texas Press, 1999), pp. 85-116

${ }^{5}$ The Art of the Tale: An International Anthology of Short Stories (ed. Daniel Halpern) (New York: Penguin, 1986).

${ }^{6}$ When I say "non-Brazilian”, in part I am basing myself on words of the author himself at an event I was present at at the Literary Festival of Hay-on-Wye, Wales, in 2002. Asked about his possible links with Brazilian religious syncretism, he strongly denied any connection.

${ }^{7}$ Interview with the author for "You, Dear reader", a radio programme on Machado de Assis, transmitted by BBC Radio 3 in 1991.

${ }^{8}$ Genius: The Hundred Most Creative Writers in the History of Literature (New York: Warner Books, 2000), pp. 545-50.

\section{Notas}

${ }^{1}$ Paris: Bayard, 2004 (p. 56); agradeço à minha tradutora, Luana Freitas, a indicação deste livro.

${ }^{2}$ A única experiência prévia de escrever sobre tradução foi um ensaio sobre três antologias inglesas da poesia de Carlos Drummond de Andrade, publicado em 1986, e republicado como apêndice ao meu livro Influências e impasses: Drummond e alguns contemporâneos (São Paulo: Companhia das Letras, 2003), pp. 281-99.

${ }^{3}$ La Traduction de la Lettre ou L'Auberge du lointain (Paris: Seuil, 1999), pp. $15-16$

${ }^{4}$ In Machado de Assis: Reflections on a Brazilian Master [Machado de Assis: reflexões sobre um mestre brasileiro]. Austin, Texas: University of Texas Press, 1999, pp. 85-116.

${ }^{5}$ The Art of the Tale: An International Anthology of Short Stories [A arte do relato: antologia internacional de contos] (ed. Daniel Halpern) (Nova Iorque: Penguin, 1986)

${ }^{6}$ Quando digo "nada brasileiro", baseio-me em parte em palavras do autor num evento que assisti no Festival Literário de Hay-on-Wye, País de Gales, em 2002. Surgindo uma pergunta sobre as possíveis ligações da sua literatura com o sincretismo religioso brasileiro, ele negou fortemente qualquer conexão.

${ }^{7}$ Entrevista com o autor para "You, Dear reader" [Tu, caro leitor], um programa de rádio sobre Machado de Assis, transmitido pela BBC Radio 3, em 1991.

${ }^{8}$ Gênio: o 100 autores mais criativos da história da literatura (tr. José Roberto O’Shea) (Rio de Janeiro: Objetiva, 2003), pp. 688-93 
${ }^{9}$ p. 545

${ }^{10}$ p. 547

11 In the end, I put the information in the Introduction, trying not to overemphasise its importance by placing it in brackets: “("Casmurro," the adjective that completes the appellation and gives the title to the book, is explained in Chapter I. If any reader is so mischievous as to disobey Bento's instructions and look it up in the dictionary, he or she will find that it normally means "stubborn, headstrong".)" See Patai, pp. 90-91 for the other two translator's options.

${ }^{12}$ Quoted in Augusto Meyer, Machado de Assis 1935-1958 (Rio de Janeiro: Livraria São José, 1958), pp. 13-14.

${ }^{13}$ Crônica for 21 August 1892; see my edition of A Semana, (São Paulo: Hucitec, 1996), p. 108.

${ }^{14}$ A Semana, ed. cit., p. 53 (1 May 1892).

${ }^{15}$ See the arguments of Hélio de Seixas Guimarães in his Os leitores de Machado de Assis: o romance machadiano e o público de literatura no século 19 (São Paulo: Nankin / Edusp, 2004

16 “Machado in English”, p. 98.

${ }^{17}$ A Master on the Periphery of Capitalism (tr. John Gledson) (Durham, N.C.: Duke University Press, 2001), pp. 7-8.

18 See Ubiratan Machado, Bibliografia machadiana 1959-2003 (São Paulo: Edusp, 2005), p. 31 (verbetes 276 and 277).
${ }^{9}$ Bloom, op. cit. p. 688

${ }^{10}$ Bloom, op. cit. p. 690

${ }^{11}$ Por fim, pus a informação na introdução e tentei não lhe dar ênfase exagerada colocando-a em parênteses: “('Casmurro', the adjective that completes the appellation and gives the title to the book, is explained in Chapter I. If any reader is so mischievous as to disobey Bento's instructions and look it up in the dictionary, he or she will find that it normally means "stubborn, headstrong".)" ['Casmurro', adjetivo que complementa o título e dá título ao livro, está explicado no capítulo 1. Se algum leitor for tão desobediente a ponto de contrariar as ordens de Bento e procurar no dicionário, ele verá que normalmente significa 'obstinado, cabeça-dura']. Ver Patai, pp. 90-1 para as duas outras opções dos tradutores.

12 Citado em Augusto Meyer, Machado de Assis 1935-1958 (Rio de Janeiro: Livraria São José, 1958), pp. 13-14.

${ }^{13}$ Crônica para 21 de agosto de 1892; ver minha edição de A Semana, São Paulo: Hucitec, 1996, p. 108.

${ }^{14}$ Crônica para 1 de maio de 1892; ver A Semana, p. 53.

${ }^{15}$ Ver os argumentos de Hélio de Seixas Guimarães em Os leitores de Machado de Assis: o romance machadiano e o público de literatura no século XIX. São Paulo: Nankin/Edusp, 2004.

16 “Machado in English”, p. 98.

${ }^{17}$ Um mestre na periferia do capitalismo (Sâo Paulo: Duas Cidades, Editora 34, 2000), pp. 17-18.

18 Ver Ubiratan Machado, Bibliografia machadiana 1959-2003. São Paulo: Edusp, 2005, p. 31 (verbetes 276 e 277) 
${ }^{19}$ The Psychiatrist and Other Stories, Berkeley: University of California Press and London: Peter Owen Ltd. (1963).

20 "Machado de Assis em inglês", in Ao redor de Machado de Assis (Rio de Janeiro: Civilização Brasileira, 1958), pp. 249-58.

21 “Machado in English”, p. 95

${ }^{22}$ By "more or less at random", I chose the passage because it is one of the most vivid in the novel, and one of the few places where Machado deals directly with slavery. The important point, however, is that I had no idea what I would find in the translations, beyond the overwhelming impression I had that Rabassa's translation was unsatisfactory: I have to say that I was shocked to find so much. As Daphne Patai says: "Comparing translations is a complex business, requiring line-by-line reading” (p. 90). It is also an effort, requiring the near-simultaneous consultation of at least three books. However, it can also be extraordinarily interesting and rewarding.

${ }^{23}$ Obra Completa (Aguilar), I, pp. 579-80

${ }^{24}$ Epitaph of a Small Winner (London: Hogarth Press, 1985), p. 128

${ }^{26}$ An excellent example can be found in the next chapter, chapter 69, "Um grão de sandice”, where Brás, having told the story of Romualdo, who "tom[ou] tanto tártaro, tanto tártaro, tanto tártaro, que fi[cou] Tártaro, e rei dos Tártaros" (which plainly points the blame at the first person to administer the "tártaro", Brás himself), then hurries past the consequences, merely saying that "a propósito de um vergalho recebido e transferido, força é confessor que é muito melhor voltar à casinha da Gamboa; deixemos os Romualdos e Prudêncios.”. Grossman decides to nudge the reader in the right direction, and adds the following sentence: "in connection with beatings received and transferred, it suggests this unpleasant thought: Is it possible that Romualdo and Prudêncio were really doing the same thing, for the same reason - although one was mad and the other was sane? An unpleasant thought. Let us return to the little house in Gamboa.” The words in italic, though perhaps suggested by last words of the
${ }^{19}$ Berkeley: University of California Press e London: Peter Owen Ltd. (1963).

20 "Machado de Assis em inglês", in Ao redor de Machado de Assis (Rio de Janeiro: Civilização Brasileira, 1958), pp. 249-58.

21 “Machado in English”, p. 95.

${ }^{22}$ A razão de este trecho ter sido escolhido “mais ou menos ao acaso” é porque é um dos mais intensos do romance e uma das poucas ocorrências em que Machado lida diretamente com a escravidão. Contudo, é importante ressaltar que eu não tinha idéia do que encontraria nas traduções, além da impressão insuperável de que a tradução de Rabassa era insatisfatória, e devo acrescentar que fiquei chocado com o nível de insatisfação. Citando Daphne Patai: "Comparing translation is a complex business, requiring line-by-line reading" [O cotejo de traduções é uma atividade complexa que exige leitura linha por linha], (p. 90). É também um esforço que exige a consulta simultânea de pelo menos três livros. Contudo, pode ser também muito interessante e gratificante.

${ }^{25}$ The Posthumous Memoirs of Brás Cubas (New York: Oxford University Press, 1997), pp. 108-09

${ }^{26}$ Um excelente exemplo pode ser visto no capítulo seguinte, o 69, “Um grão de sandice”, em que Brás, depois de contar a história de Romualdo, que "tom[ou] tanto tártaro, tanto tártaro, tanto tártaro, que fic[ou] Tártaro, e rei dos Tártaros" (que claramente põe a culpa na primeira pessoa que tomou o tártaro, o próprio Brás), passa logo às conseqüências, dizendo simplesmente que “a propósito de um vergalho recebido e transferido, força é confessor que é muito melhor voltar à casinha da Gamboa; deixemos os Romualdos e Prudêncios”. Grossman opta por indicar ao leitor a interpretação correta e acrescenta o seguinte: "in connection with beatings received and transferred, it suggests this unpleasant thought: Is it possible that Romualdo and Prudêncio were really doing the same thing, for the same reason - although one was mad and the other was sane? An unpleasant thought. Let us return to the little house in Gamboa." [isto sugere uma idéia desagradável: É possivel que Romualdo e Prudêncio estivessem de 
Portuguese, are surely an unwarranted intervention, intended to clarify what Machado wanted to keep (to a point) obscure.

${ }^{27}$ Perhaps the edition with the best notes in Portuguese is the Scipione edition (São Paulo, 1994), which contains Memórias póstumas and Quincas Borba. The notes, which are a model of reliability and common sense, were the responsibility of Cristina Carletti.

28 “'Nhonho' (applied to Virgilia's son and to Braz) and 'Yaya' (applied to Virgilia) were common nicknames for male and female children, respectively, of well-to-do families.” Epitaph of a Small Winner (London: Hogarth Press, 1985).

${ }^{29}$ He justifies his decision to do a new translation by his dissatisfaction with the title of Grossman's translation, Epitaph of a Small Winner, which he calls “asinine”, a strong word in the circumstances. Wouldn't it have been cheaper to buy the rights and change the title? If this be Treason: Translation and its Dyscontents: a Memoir (New York: New Directions, 2005), p. 158.

${ }^{30}$ If this be Treason, p. 138

${ }^{31}$ Another example, which unfortunately has affected another Brazilian writer, are Giovanni Pontiero's translations of, for instance, Laços de família, which heavily normalise the strangeness which is so vital to her style and personality as a writer. Yet Pontiero's translations of Saramago, who might be seen as a much more difficult writer, are excellent.

${ }^{32}$ A Master on the Periphery of Capitalism, p. 18. fato fazendo o mesmo, pela mesma razão - apesar de um ser louco e o outro são? Uma idéia desagradável.] O trecho em itálico, embora talvez sugerido pelas últimas palavras em português, é sem dúvida uma intervenção imperdoável que pretende esclarecer o que Machado queria manter (até certo ponto) obscuro.

${ }^{27}$ A edição com as melhores notas em português é possivelmente a da Scipione (São Paulo, 1994), que compreende Memórias póstumas de Brás Cubas e Quincas Borba. As notas, exemplos de confiabilidade e bom senso, são responsabilidade de Cristina Carletti.

28 “ 'Nhonho' (applied to Virgilia's son and to Braz) and 'Yaya' (applied to Virgilia) were common nicknames for male and female children, respectively, of well-to-do families." Epitaph of a Small Winner (London: Hogarth Press, 1985)

${ }^{29}$ Ele justifica a decisão de fazer uma nova tradução, dizendo que não gostou do título da de Grossman, Epitaph of a Small Winner, que ele chama de "asinine”, palavra um tanto forte. Não teria sido mais econômico comprar os direitos e mudar o título? (If this be Treason, p. 158).

${ }^{30}$ Gregory Rabassa, If this be Treason: Translation and its Dyscontents: a Memoir. [Se for traição: Tradução e seus dissabores: uma autobiografia]. Nova York: New Directions, 2005, p. 138.

${ }^{31}$ Um segundo exemplo que infelizmente afetou outra escritora brasileira foram as traduções de Giovanni Pontiero de, por exemplo, Laços de família, de Clarice Lispector, que normalizou consideravelmente o estranhamento tão vital ao estilo e a personalidade da escritora. Todavia, suas traduções de Saramago, que poderia ser considerado um escritor muito mais difícil, são excelentes.

${ }^{32}$ Um mestre na periferia do capitalismo, p. 18. 
${ }^{33}$ A Master on the Periphery of Capitalism, p. 2.

${ }^{34}$ Here I must acknowledge the help of Iuri Abreu, one of my students at UFSC, who downloaded the texts of all the novels and most of the stories from the internet. These have been invaluable in enabling quick searches to be made for words which often only appear once or twice, as well as for finding quotations one has half-remembered, or can only remember one word from.

36 “O machete e o violoncelo”, Contos: uma antologia (São Paulo: Companhia das Letras,1999), pp. 47-49

${ }^{37}$ Revista USP, 10 (julho-agosto 1991) pp. 161-64

${ }^{38}$ Even Helen Caldwell, who avoids notes, is forced to append one here. See The Psychiatrist and Other Stories, p. 67.

${ }^{40}$ A good example is Capitu's “Que tem, tem”, in Chapter 32 of Dom Casmurro, which is a simple expression of impatience with Bentinho's prevarication. Caldwell translates "But she is, she is", which fails (to my ear) to get the right note - she's not insistent, or trying to persuade Bentinho, she's impatient. I translated "Of course she has".

${ }^{41}$ At a recent conference in Florianópolis, Hélio Guimarães provided a lot of evidence in this regard. And, as we have found out since, Arnaldo Saraiva has discovered that Memórias póstumas de Brás Cubas was published in the Folha Nova in Porto in 1883, though abandoned after the $28^{\text {th }}$ Chapter. See Abel Barros Baptista’s edition of the novel, (Lisbon: Cotovia, 2005), p. 333.
${ }^{33}$ Um mestre na periferia do capitalismo, p. 11.

${ }^{34}$ Neste momento, devo agradecer a ajuda de Iuri Abreu, um aluno meu da UFSC, que baixou da rede os textos de todos os romances e da maior parte dos contos. Esta ajuda inestimável possibilitou a agilização nas buscas de palavras que aparecem somente uma ou duas vezes, bem como a localização de citações das quais só se lembra uma parte.

35 James L. Taylor A Portuguese-English Dictionary (Londres: Harrap. 1959), p. 233

36 "O machete e o violoncelo”, Contos: uma antologia (São Paulo: Companhia das Letras, 1999), pp. 47-49.

${ }^{37}$ Revista USP, 10, junho-agosto 1991, pp. 161-66.

38 Até Helen Caldwell, que evita notas, é forçada e fornecer esta informação: The Psychiatrist and Other Stories, p. 67.

39 “O machete e o violoncelo” (introdução a Contos: uma antologia), p. 48.

${ }^{40}$ Um bom exemplo é o da frase de Capitu: “que tem, tem”, do capítulo 32 de Dom Casmurro, uma simples expressão de impaciência com as evasivas de Bentinho. Caldwell traduz: "But she is, she is", que (para os meus ouvidos) não transmite a idéia certa - ela não insiste nem tenta persuadir Bentinho, ela está impaciente. Traduzi: "Of course she has” [Claro que ela tem].

${ }^{41}$ Em uma recente palestra em Florianópolis, Hélio Guimarães forneceu vários elementos a esse respeito. E, como descobrimos desde então, Arnaldo Saraiva descobriu que Memórias póstumas de Brás Cubas foi publicado na Folha Nova no Porto em 1883, mas foi deixado de lado no $28^{\circ}$ capítulo. Ver a edição de Abel Barros Baptista do romance. (Lisboa: Cotovia, 2005, p. 333) 
John Gledson

J.A.Gledson@liverpool.ac.uk Liverpool University

Tradução de:

Luana Ferreira de Freitas

luanafreitas.luana@gmail.com

Universidade Federal do Ceará 